\title{
Mozart y Salieri: entre naturaleza y razón de la creación artística
}

\section{Mozart and Salieri: between the Nature and Reason of Artistic Creation}

Artículo recibido el 29 de marzo de 20I9; devuelto para revisión el ro de abril de 2020; aceptado al 8 de junio de 2020; https://doi.org/IO.2220I/iie.I8703062e.2020.117.2728

Arturo García Gómez Universidad Michoacana de San Nicolás Hidalgo, artuchik@yahoo.com, https://orcid.org/oooo-oooI-7028-1387

Olga Chkourak Universidad Michoacana de San Nicolás Hidalgo, chkourak@yahoo. com.mx; https://orcid.org/oooo-oooI-6285-4499.

Líneas de investigación Musicología sistemática; teoría de la entonación; origen y evolución social de la música.

Lines of research Systematic musicology; theory of intonation; origin and social evolution of music.

Publicación más relevante "Carta a un tal Barón von... de W. A. Mozart sobre el proceso creativo", Anales del Instituto de Investigaciones Estéticas XXXIX, núm. IIO (2017): 9-48.

Resumen El artículo trata sobre la mistificación de la muerte de Wolfgang Amadeus Mozart, y su dramatización en la obra del poeta ruso Alexander Serguéyevich Pushkin titulada: Mozart y Salieri. Su objetivo es mostrar, mediante los antecedentes y el análisis de esta obra, el inestable equilibrio de los principios de la creación artística que el romanticismo descubre en el mito mozartiano. El poeta lleva este mito a la tragedia. Sus personajes representan el eterno conflicto de la creación artística entre

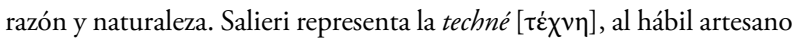

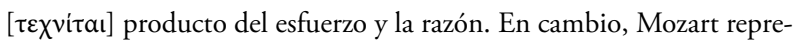

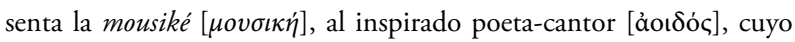
arte solo proviene del don divino otorgado por las Musas.

Palabras clave Alexander Pushkin; Wolfgang Amadeus Mozart; Antonio Salieri; genio; naturaleza; razón.

Abstract This article deals with the mystification of Wolfgang Amadeus Mozart's death, and its dramatization in the play Mozart and Salieri by Russian 
poet Alexander Serguéyevich Pushkin. The analysis of the piece and a revision of its context will reveal the unstable equilibrium of the principles of artistic creation discovered by the Romantics in the Mozartian myth. In the play, Pushkin gives this myth a tragic interpretation. Its characters represent the eternal conflict between reason and nature in

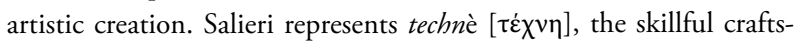
man $[\tau \varepsilon \chi v i \tau \alpha \iota]$ who is the result of effort and thought. Mozart, on the

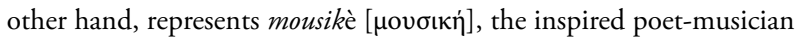

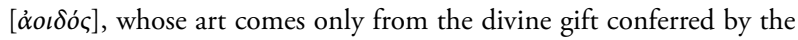
Muses.

Keywords Alexander Pushkin; Wolfgang Amadeus Mozart; Antonio Salieri; genius; nature; reason. 
https://doi.org/10.22201/iie.18703062e.2020.117.2728

\author{
ARTURO GARCÍA GÓMEZ Y OLGA CHKOURAK \\ UNIVERSIDAD MICHOACANA DE SAN NICOLÁS HIDALGO
}

\title{
Mozart y Salieri: \\ entre naturaleza y razón de la creación artística
}

$\mathrm{P}$ or más de doscientos años Wolfgang Amadeus Mozart ha sido la figura mítica del arte musical, al personificar el mito romántico de la inspiración divina en pleno Siglo de las Luces. Mozart fue tal vez el primer músico cortesano que anheló ser un artista libre, un músico dueño de sí mismo que vislumbraba ya el romanticismo. Pero en esta lucha por su libertad creadora, Mozart se enfrentó a la envidia y mediocridad del músico cortesano por la escena operística del teatro vienés. Sin duda su principal obstáculo fue el Kapellmeister y compositor de la corte, Antonio Salieri, que pasaría a la historia no como el compositor de La Fiera di Venezia, Tarare, o Axur re d'Ormus, sino como el asesino de Mozart.

De la extraordinaria capacidad creadora de Mozart se ha erigido toda una leyenda, repleta de anécdotas sobre sus hazañas artísticas. Pero no sólo de su obra y su genio se ha forjado el mito, sino también de su vida, y, sobre todo, de su repentina muerte. Las circunstancias de su enfermedad, y la ausencia de una auténtica tumba, robustecen su leyenda. ${ }^{\mathrm{I}}$

I. Se afirma que Mozart fue enterrado en una fosa común del cementerio de San Marx, en los suburbios de Viena. En realidad era una tumba perteneciente a la ciudad, que tras diez años tenía el derecho de exhumar los cuerpos y utilizar nuevamente la tumba. Según la leyenda, al exhumar el cuerpo de Mozart en I8oI, el sepulturero Joseph Rothmayer conservó su "valioso" cráneo, que le dio a su sucesor Jos Radschopf, y éste a su vez al sepulturero y músico Jacob Hyrtl en I842. En I868 su hermano, el anatomista Joseph Hyrtl, hereda el cráneo. En I9or el supuesto cráneo de Mozart llegó a la colección del Museo del Mozarteum en Salzburgo. A la fecha se sigue investigando sobre la autenticidad del cráneo, y las causas de la muerte de Mozart. 
En 1945 Alfred Einstein afirmaba que: "Hay una extraña clase de ser humano en el que existe una eterna lucha por dominar entre cuerpo y alma, entre animal y dios. En todo gran hombre esta mixtura es notable, y en nadie más que en Wolfgang Amadeus Mozart."2 Esta afirmación se confirma plenamente en la composición del Réquiem. Cuando la energía vital de su cuerpo se extinguía en la enfermedad final, su espíritu se revelaba como portador de un toque divino. Se podría afirmar que el Réquiem fue el umbral del romanticismo como primera expresión musical de lo sublime, de lo inconmensurable, que la razón no alcanza a comprender, pero el espíritu sí intuye su grandeza.

Robins Landon señala que la música de Mozart nos invita a entrar en el mundo de sus emociones: "es como si nos tomara de la mano y nos guiara, exigiendo que le sigamos adonde él vaya. De ahí que hagamos nuestras sus alegrías y sus penas". ${ }^{3} Y$ añade que el dramatismo de sus óperas, y la revelación de la verdad y belleza en el Réquiem, austero y sobrecogedor, son el producto más inspirado de la Ilustración. Su legado es sin duda una de las mejores excusas que jamás encontraremos para la existencia humana.

\section{La muerte de Mozart}

Tras dos siglos de su muerte, acaecida el 5 de diciembre de I79I, se sigue especulando sobre las causas del fallecimiento de Mozart. En la extensa bibliografía dedicada al tema, se afirma que Mozart había sido un niño enfermizo, y tuvo problemas de salud a lo largo de toda su vida. Sin embargo, en noviembre de I79I su salud se deterioró aún más. ${ }^{4}$ El certificado de defunción sugiere que "murió de una aguda fiebre miliar". Según el testimonio de los presentes en su

Véase Bernard Puech et al., "Cranofacial Anomalies and Pathology", Anthropologie 28, núm. I (I999): 67-78.

2. "There is a stranger kind of human being in whom there is an eternal struggle between body and soul, animal and god, for dominance. In all great men this mixture as striking, and in none more so than in Wolfgang Amadeus Mozart", en Alfred Einstein, Mozart. His Character, His work (Londres: Oxford University Press, 1945), 3 (trad. del autor).

3. H. C. Robins Landon, I79I: El último año de Mozart (Madrid: Siruela, 2006), I4.

4. Véase Peter J. Davies, "Mozart's Illnesses and Death-I. The Illnesses, I756-I790", The Musical Times I25, núm. I698 (agosto de 1984): 437-42; y Richard H. C. Zegers, Andreas Weigl y Andrew Steptoe, “The Death of Wolfgang Amadeus Mozart: An Epidemiologic Perspective”, Annals of Internal Medicine I5I, núm. 4, (2009): 274-280.

5. "Am hitzigen Frieselfieber gestorben", en "Hauptpfarramt St. Esteban, Todtenschein von 
lecho de muerte: "La enfermedad mortal que lo mantuvo postrado en cama, duró is días. Comenzó con la hinchazón de manos y pies, y casi una completa inmovilidad; seguido de un súbito vómito, por lo que pudo denominarse a esta enfermedad como una aguda fiebre miliar." 6

No obstante, los síntomas hicieron creer a muchos que se trataba de envenenamiento. En una carta enviada a la revista berlinesa Musikalisches Wochenblatt, fechada en Praga el I2 de diciembre de I79I, se menciona: "Mozart está muerto. Regresó a casa de Praga enfermo, y desde entonces siempre enfermo; se considera hidropesía, y murió en Viena el fin de semana pasado. Ya que su cadáver estaba hinchado, se cree que fue envenenado."

En la primera biografía de Mozart, Adolf Heinrich Friedrich Schlichtegroll no menciona las circunstancias de su enfermedad. ${ }^{8}$ Pero la sospecha de envenenamiento fue cobrando fuerza en sucesivas publicaciones, basada sobre todo en los testimonios de su viuda Constanze Maria Weber, recopilados por varios

Wolfgang Amadé Mozart. Wien, 5. Dezember 179I", en Mozart Briefe und Dokumente, consultado el 5 de mayo de 20I8, en http://dme.mozarteum.at/DME/briefe/letter.php?mid=23\&cat= (trad. del autor).

6. "Seine Todeskrankheit, wo er bettlägerig wurde, währte is Tage. Sie begann mit Geschwulst an Händen und Füssen und einer beynahe gänzlichen Unbeweglichkeit: derselben, der später plötzliches Erbrechen folgte, welche Krankheit man ein hitziges Frieselfieber nannte", en Georg Nikolaus von Nissen, Biographie W. A. Mozart's. Nach Originalbriefen (Leipzig: Breitkopf und Härtel, I828), 572 (trad. del autor).

7. "Mozart ist — todt. Er kam von Prag kränklich heim, siechte seitdem immer; man hielt ihn für wassersüchtig, und er starb zu Wien, Ende voriger Woche. Weil sein Körper nach dem Tode schwoll, glaubt man gar, daß er vergiftet worden”, Musikalisches Wochenblatt, XII, I79I, en Johann Friedrich Reichardt, ed., Musikalisch Monathsschrift (Berlín, 1793), 94 (trad. del autor).

8. Adolf Heinrich Friedrich Schlichtegroll, Nekrolog auf das Jahr I79I, "Nachrichten von dem Leben merkwürdiger in diesem Jahre verstorbener Personen”, II Jahrgang, II Band (Gotha: Justus Perthes, I793), 82-II2. Se publicó al año siguiente como Mozarts Leben (Graz, I794). A. H. Friedrich Schlichtegroll (1765-1822) no conoció personalmente a Mozart. En mayo de 1792 pidió información a Albert von Mölk, conocido de la familia Mozart en Salzburgo, quien consultó a la hermana de Wolfgang, Maria Anna (Mozart) von Berchtold zu Sonnenburg. Ella, a su vez, solicitó la ayuda de Johann Andreas Schachtner (I73I-I795), escritor y músico, cercano amigo de la infancia de Wolfgang. Véase "Friedrich Schlichtegroll an Albert von Mölk in Salzburg, Gotha, 25. Mai 1792", Mozart Briefe und Dokumente, consultado el 5 de mayo de 2018, en http://dme.mozarteum.at/DME/briefe/letter.php?mid=27\&cat=; y Georges Favier, ed., Vie de W. A. Mozart par Franz Xaver Niemetschek précédée du nécrologe de Schlichtegroll (St. Etienne: Université de Saint-Etienne-Centre Interdisciplinaire d'Études et Recherches sur L'Expression Contemporaine, 1976). 
autores; entre ellos su segundo esposo, el diplomático danés Georg Nikolaus von Nissen (I76I-I826).

En 1798 Franz Xaver Niemetschek publicó una monografía de Mozart con base en la obra de Schlichtegroll, más anécdotas de amigos y conocidos que Constanze Maria Weber le había confiado. ${ }^{9}$ Niemetschek afirma que su enfermedad final inició durante su visita a Praga en agosto y septiembre de I79I, cuando supervisaba la representación de La clemenza di Tito, dedicada a la coronación de Leopoldo II. Poco antes de viajar a Praga, Mozart recibió una carta sin remitente de un misterioso mensajero, preguntando si aceptaba escribir una misa de réquiem; con qué precio y cuánto tiempo requería. Sin el conocimiento de su esposa, Mozart no quiso comprometerse; aunque lo haría por una recompensa segura. Mientras tanto, Mozart siguió con el encargo de $L a$ clemenza di Tito. Pero justo antes de partir a Praga, apareció de nuevo el misterioso mensajero preguntando por el réquiem:

Justamente cuando Mozart y su esposa subían al coche, apareció el mensajero como un fantasma, y tirando de la capa de la mujer preguntó: — “Qué va a ser del Réquiem?-_", Mozart se disculpó, diciendo que el viaje era necesario y explicando que le había sido imposible dar noticias de ello a su benefactor desconocido, pero que en cuanto volviera sería lo primero que emprendería; el mecenas desconocido debía decidir si le convenía o no esperar tanto tiempo, pero el mensajero se quedó enteramente satisfecho con la respuesta. Ya en Praga, Mozart enfermó y lo medicaron continuamente. Estaba pálido y el semblante triste [...]. De regreso a Viena, tomó al instante su réquiem, y trabajó con mucho esfuerzo y vivo interés. ${ }^{10}$

9. Franz Xaver Niemetschek (I766-I849). Músico y escritor checo. En I80o obtiene su doctorado, y dos años después ocupa el puesto de profesor de filosofía en la Universidad de Praga. Vio en la obra de Mozart la expresión de sus ideales estéticos. Véase Ernst Rychnovsky, ed., W. A. Mozart's Leben nach Originalquellen beschrieben von Franz Niemetschek (Praga: T. Caussig, 1903), V-XI.

Io. "Eben als Mozart mit seiner Frau in den Reisewagen stieg, stand der Bothe wie ein Geist da, zupfte die Frau an dem Rocke, und fragte: ,Wie wird es nun mit dem Requiem aussehen? - Mozart entschuldigte sich mit der Nothwendigkeit der Reise und der Unmöglichkeit seinem unbekannten Herrn davon Nachricht geben zu können; übrigens würde es seine erste Arbeit bey der Zurückkunft seyn, und es käme nur auf den Unbekannten an, ob er solange warten wolle. Damit war der Bothe gänzlich befriedigt. Schon in Prag kränkelte und medizinirte Mozart unaufhörlich; seine Farbe war blaß und die Miene traurig. [...] Bey seiner Zurückkunft nach Wien nahm er sogleich seine Seelenmesse vor, und arbeitete mit viel Anstrengung und einem lebhaften Interesse daran.”, en Franz Xaver Niemetschek, Leben des K. K. Kapellmeisters 
De vuelta en Viena, Mozart siguió trabajando en Die Zauberflöte, que dirigió el 30 de septiembre en el Freyhaustheater de Emanuel Schikaneder, del barrio vienés de Wieden. En octubre compuso el Klarinette Konzert A-Dur. En noviembre la cantata Eine kleine Freymaurer-Kantate, con texto de Schikaneder para la logia masónica Zur gekrönte Hoffnung (La esperanza coronada), y continuó con la composición de su última obra, Die Seelenmesse (Réquiem), que según la leyenda fue la causa de su muerte.

Más adelante Niemetschek narra otra anécdota de Constanze, en la que Mozart insinúa durante un paseo por el parque vienés Prater, en el otońo de I79I, la sospecha de haber sido envenenado: "Su esposa estaba afligida. Un día paseando con él en el Prater para distraerlo y animarlo, cuando ambos estaban sentados, Mozart comenzó a hablar de la muerte y afirmó que escribía el Réquiem para sí mismo. Las lágrimas corrieron por los ojos del sensible hombre. 'Presiento', dijo después, 'que no permaneceré más tiempo: ¡seguro que he sido envenenado! No puedo liberarme de esta idea."."

La misma historia del Réquiem, sin mencionar el envenenamiento, fue publicada en diciembre de ese año (1798) en la revista Allgemeine Musikalische Zeitung de Leipzig por Friedrich Johann Rochlitz, su editor, como parte de Verbürgte Anekdoten aus Wolfgang Gottlieb Mozarts Leben, una recopilación de anécdotas y testimonios "verídicos" sobre la vida de Mozart, que concluyó en mayo de I80I. ${ }^{\mathrm{I2}}$ Rochlitz escribe:

Wolfgang Gottlieb Mozart nach Originalquellen beschrieben (Praga, I798), 33-34; citado también en Nissen, Biographie W. A. Mozart's, 555-56 (trad. del autor y de Gabriela Bustelo en Landon, I79I: El último año de Mozart, II6).

II. "Seine Gattin nahm es mit Betrübnis wahr. Als sie eines Tages mit ihm in den Prater fuhr, um ihm Zerstreuung und Aufmunterung zu verschaffen, und sie da beide einsam saßen, fing Mozart an vom Tode zu sprechen und behauptete, daß er das Requiem für sich setze. Tränen standen dem empfindsamen Manne in den Augen. Ich fühle mich zu sehr, sagte er weiter, mit mir dauert es nicht mehr lange: gewiß, man hat mir Gift gegeben! Ich kann mich von diesem Gedanken nicht los winden'”, en Niemetschek, Leben des Kapellmeisters Wolfgang Gottlieb Mozart, 34 (trad. del autor).

I2. Friedrich Johann Rochlitz (I769-I842). Crítico, escritor y editor alemán. En I798 inicia como editor de la Allgemeine Musikalische Zeitung, que durante cincuenta ańos fue la revista musical más influyente de Europa. También fue director de la Leipzig Gewandhause Orchestra. Estos dos puestos lo consolidaron como uno de los críticos más influyentes de su tiempo. Véase F. Johann Rochlitz, "Selbstbiographie. Zur Geschichte meines Lebens in Hinsicht auf Musik", Allgemeine Musikalische Zeitung Xuv (1843): I25-I28; y, Maynard Solomon, "The Rochlitz Anecdotes: Issues of Authenticity in Early Mozart Biography”, en Cliff Eisen, ed., Mozart Studies (Oxford: Clarendon Press, I99I), I-59. 
Un día, cuando estaba ahí sentado en melancólicas fantasías, llegó un carruaje y un desconocido pidió que lo anunciaran. Él [Mozart] lo recibió. Entró un hombre de mediana edad, serio, imponente, con una expresión muy solemne, desconocido tanto para él como para su esposa. - Vengo a verle en calidad de mensajero de un caballero muy distinguido - le dijo el hombre — ¿Quién le envía? - preguntó Mozart. - El caballero no desea darse a conocer.- Bien, ¿qué desea de mí? - Alguien muy querido y cercano a esta persona ha muerto; desea recordar el día de su muerte, en recogimiento pero con dignidad, y solicita que usted componga un réquiem con ese fin. Mozart, en vista de su estado de ánimo en aquel momento, ya estaba muy conmovido por la conversación; por el misterio que envolvía todo aquel asunto; por el tono solemne de aquel hombre. Prometió hacer lo que se le pedía. El hombre continuó: - Llévelo a cabo con la mayor diligencia posible; el caballero es un entendido.- - Tanto mejor. — No estará sujeto a ninguna fecha de entrega.-Excelente. —_Aproximadamente cuánto tiempo precisará usted? - Unas cuatro semanas. — Entonces volveré a recoger la partitura. ¿Cuáles son sus honorarios? Mozart, sin pensar, contestó: - Cien ducados. "Aquí tiene" dijo el hombre, que puso el rollo de monedas sobre la mesa y se marchó. Mozart volvió a quedarse profundamente ensimismado; no prestó atención a los ruegos de su mujer, hasta que finalmente pidió pluma, tinta y papel. Se puso inmediatamente a componer el encargo. Su interés en el asunto iba creciendo con cada compás; pasaba día y noche escribiendo. Su cuerpo no lograba soportar un esfuerzo semejante; se desmayó varias veces mientras trabajaba. Todas las exhortaciones a la moderación fueron en vano. Al cabo de unos días su esposa logró convencerle de que fuera al Prater con ella en coche. Él permanecía silencioso y absorto en sus ideas. Finalmente le confesó: estaba convencido de estar componiendo aquella obra para su propio entierro. Todos los intentos de disuadirle de esta idea fueron vanos; trabajaba, por tanto, como Rafael en su Transfiguración, con la sensación omnipresente de la proximidad de su muerte..$^{13}$

13. "Al er eines Tages auch in solche schwermüthige Phantasieen versenkt da sass, fuhr ein Wagen vor und ein Fremder liess sich melden. Er nahm ihn an. Ein etwas bejahrter, ernsthafter, stattlicher Mann, von sehr würdigem Ansehen, den weder er noch seine Gattin kannte - trat herein. Der Mann begann: „Ich komme als Abgesandter eines sehr angesehenen Mannes zu Ihnen“„Von wem kommen Sie?“ fragte Mozart. „Der Mann wünscht nicht gekannt zu seyn“ —,Gut — was verlangt er von mir?“ „Es ist ihm eine Person gestorben, die ihm sehr theuer ist und ewig seyn wird; er würdig zu feyern, und bitte Sie ihm dazu das Requiem zu komponieren." — Mozart war durch diese Rede; durch das Dunkel, welches über die ganze Sache verbreitet war; durch die Feyerlichkeit des Tons des Mannes, bey seiner jetzigen Gemüthsstimmung, schon innig ergriffen, 
$\mathrm{Al}$ no mencionar lo del envenenamiento, Rochlitz se alineaba a la hipótesis de una muerte natural debido a su extenuante trabajo, haciendo una comparación entre la Transfiguración del pintor renacentista Rafael Sanzio y el Réquiem de Mozart, quienes con todas sus energías al servicio del arte rebasan el límite de sus fuerzas físicas, para crear una gran obra. ${ }^{14}$ Esta idea es desarrollada más adelante por Rochlitz en "Raphael und Mozart".

und versprach das Verlangte zu thun. Der Mann fuhr fort: „Arbeiten Sie mit allem möglichen Fleiss: Der Mann ist Kenner“—„Desto besser“—_Sie werden durch keine Zeit beschränkt“— „Vortrefflich“—,Wie viel Zeit bestimmen Sie sich ohngefähr?““ Mozart, der Zeit und Geld selten zu überrechnen pflegte, antwortete: „Etwa vier Wochen“—,Dann komme ich wieder und hole die Partitur. Wie viel verlange Sie Honorarium?“ Mozart antwortete leicht hin: „Hundert Dukaten“—,Hier sind sie“— sagte der Mann: legte die Rolle auf den Tisch und ging. Mozart versank von neuem in tiefes Nachdenken, hörte auf die Zuredungen seiner Gattin nicht, und forderte endlich nur Feder, Tinte und Papier. Er fing sogleich an an dem Verlangten zu arbeiten. Mit jedem Takt schien sein Interesse an der Sache zuzunehmen: er schrieb Tag und Nacht. Sein Körper hielt die Anstrengung nicht aus: er sank über dem Arbeiten einigemal in Ohnmacht. Alles Zureden zur Mässigung in der Arbeit war vergebens. Nach einigen Tagen erst erhielt es seine Frau über ihn, daß er mit ihr in den Prater fuhr. Er saß immer still und in sich gekehrt. Endlich verleugnete er es nicht mehr — er glaube gewiß, er arbeite dies Stück zu seiner eignen Todesfeyer. Von dieser Idee ließ es sich nicht abbringen; arbeitete also, wie Raphael seine Verklärung, stets im Gefühl seines nahen Todes.”, en F. Johann Rochlitz, Allgemeine Musikalische Zeitung, núm. IO, 5 de diciembre de 1798, en: "Anekdoten aus Mozarts Leben”, Allgemeine Musikalische Zeitung, Erster Jahrgang, del 3 de octubre de 1798 al 25 de septiembre de 1799 (Leipzig: Breitkopf und Härtel, I799), I49-I5I (trad. de Gabriela Bustelo en Landon, I79I: El último año de Mozart, 90-9I).

I4. Franz von Walsegg (1763-1827) fue el contratista anónimo del Réquiem, para conmemorar la prematura muerte de su esposa. Siendo músico amateur, Walsegg tuvo la mala reputación de comisionar obras e interpretarlas como propias. El encargo se hizo por medio de un misterioso mensajero a su servicio, Franz Anton Leitgeb. De acuerdo con el reporte del violinista Anton Herzog, titulado: "Wahre und ausführliche Geschichte des Requiem von W. A. Mozart. Vom Entstehen desselben im Jahre 179I bis zur gegenwärtigen Zeit I839", conservado en el archivo municipal de Wiener-Neustadt, el Réquiem fue dirigido por Walsegg en la Abadía cisterciense de Wiener-Neustadt el I4 de diciembre de I793, aunque ya había sido interpretado el 2 de enero de ese año en Viena, a beneficio de Constanze Maria viuda de Mozart, que organizó el barón Gottfried van Swieten. Véase Otto Erich Deutsch, "Zur Geschichte von Mozarts Requiem”, Österreichische Musikzeitschrift, I9. Jahrgang, Heft 2 (febrero de 1964): 49-60; y Landon, I79I: El último año de Mozart, 89-100.

I5. F. Johann Rochlitz, "Raphael und Mozart", Allgemeine Musikalische Zeitung, núm. 37, II de junio de I800 (Leipzig: Breitkopf und Härtel, I800): 64I-65I. La Trasfigurazione, obra del pintor renacentista Rafael Sanzio (I483-I520) — fue pintada de I5I7 a I520 por encargo del cardenal Giulio de Medici, futuro Papa Clemente VII. Rafael muere prematuramente el 6 de abril de I520, a los 37 años, y La Trasfigurazione queda inconclusa. Se cree que fue completada 
En reiteradas ocasiones Mozart había manifestado esta obsesión por la proximidad de su muerte. En una carta fechada el 4 de abril de 1787 , Mozart escribe a su padre: " $¡ M$ Mon très cher père! [...] Porque la muerte (como tal) es la verdadera finalidad de nuestras vidas, hace ya varios años que mantengo una relación estrecha con este amigo, el mejor y más verdadero de nuestras vidas, de forma que su imagen ya no sólo no me resulta aterradora, ¡sino que se ha convertido en algo apaciguante y reconfortante!"16

Esta apacible aceptación de la muerte fue advertida por el poeta Franz Alexander von Kleist (1769-1797), en su relato Die Opergesellschaft del viernes 2 de septiembre de I79I, a sólo tres meses de la muerte de Mozart. Kleist describe la representación de Il dissoluto punito ossia: Il D. Giovanni, en el Teatro Nacional de Praga durante los festejos de la coronación de Leopoldo II, al que asistió como espectador el mismo Mozart. Tras mencionar al emperador y una serie de notables asistentes, Kleist escribe:

Olvidémonos de estas personas, se me ocurren ideas mejores al ver un hombre bajito, con un abrigo verde, cuyos ojos revelan aquello que su modesta condición oculta. Es Mozart, cuya ópera Don Juan se ofrece hoy, que tiene el placer de ver el deleite que producen sus hermosas armonías en los corazones del público. ¿Quién puede estar más orgulloso y feliz que él? ¿Quién puede estar más satisfecho de sí mismo? En vano derrocharían los monarcas sus fortunas y quienes se jactan de noble linaje sus riquezas; ;no pueden comprar ni una diminuta chispa del sentimiento con que el Arte recompensa a sus elegidos! [...] Todos debemos temer la muerte, sólo el artista no la teme. Su inmortalidad no es su esperanza, es su certeza $[\ldots]$ en aquel momento hubiera preferido ser Mozart antes que Leopoldo. ${ }^{17}$

por su alumno Giulio Romano. De ahí el paralelismo que Rochlitz hace de estas dos obras inconclusas, el Réquiem y La Trasfigurazione, debido a la repentina muerte de ambos artistas.

I6. "Mon très cher père! [...] Da der Tod (genau zu nehmen) der wahre Endzweck unseres Lebens ist, so habe ich mich seit ein paar Jahren mit diesem wahren, beste Freunde des Menschen so bekannt gemacht, daß sein Bild nicht allein nichts Schreckendes mehr für mich hat, sondern sehr viel Beruhigendes und Tröstendes!", en Ludwig Nohl, Mozarts Briefe nach den Originalen herausgegeben (Salzburgo: Mayr, I865), 347 (trad. del autor).

17. "Fort! mit diesen Menschen; mir winkt zu schöneren Bemerkungen dort ein kleiner Mann, in grünen Rocke, dessen Auge verräth, was sein bescheidener Anstand verschweigt. Es ist Mozart, dessen Oper, Don Juan, heut gegeben wird, der die Freude hat, selbst das Entzücken zu sehen, in welches seine schöne Harmonie die herzen aller Zuschauer versehrst. Wer im ganzen hause kann stolzer und froher senn, als er? Wer gewährt sein eignes Selbst mehr Befriedigungen, als ihm? Umsonst würden Monarchen Schasse verschwenden, umsonst der Ahnenstolz 
La anécdota del Prater citada por Niemetschek en I798, cuando Mozart confiesa haber sido envenenado, es reproducida por el organista y escritor Ignaz Ferdinand Arnold (I774-1812), en su obra: Mozarts Geist de I803: "Presiento, dijo después, que no permaneceré más tiempo: ¡seguro que he sido envenenado! No puedo liberarme de esta idea." ${ }^{18}$ No obstante, Arnold señala que tras preguntar a los médicos sobre sus hábitos, afirma que su enfermedad no pudo ser causada por el envenenamiento de algún polvo en una carta, ni por el Réquiem. Su cuerpo y alma se extenuaron; se secaron por su modo de vida: "Consumtio dorsalis. [...] La historia de la enfermedad de Mozart no señala ningún veneno. Para envenenarse hay dos formas; una rápida y otra lenta. La rápida no se percibe; y el envenenado lento, lo que él tenía — que llamamos agua tofana-, debió ser completamente a otra causa." ro

$\mathrm{Al}$ mencionar el agua tofana en su refutación a la hipótesis del envenenamiento de Mozart, contrariamente a sus intenciones, Ignaz F. Arnold reavivó esta misma teoría, sobre todo después de su muerte en I8I2. Para ese entonces, la celebridad del envenenamiento y la historia del Réquiem era tal, que en París Henri Beyle (I783-I842), más conocido como Stendhal, publicó bajo el pseudónimo de Louis Alexandre-César Bombet, Une vie de Mozart (I8I4), citando

seine Reichthümer; er kann auch nicht ein Fünkchen dieses Gefühls erkaufen, mit welchem die Kunst ihren Geliebten belohnt! [...] Alles muß den Tod Fürchten; der Künstler fürchtet ihn nicht. Seine Unsterblichkeit ist nicht Hoffnung, sie ist Gewißheit! [...] ich wünschte in diesen Augenblicken lieber Mozart als Leopold zu sehn”, en Franz Alexander von Kleist, Phantasien auf einer Reise nach Prag (Dresden y Leipzig: Richterschen Buhhandlung, 1792), 90-9I (trad. de Gabriela Bustelo en Landon, I79I: El último año de Mozart, I28).

I8. "Ich fühle mich zu sehr, sagte er weiter, mit mir dauert es nicht mehr lange: gewiß, man hat mir Gift gegeben! Ich kann mich von diesem Gedanken nicht los winden”, en Ignaz Ferdinand Arnold, Mozarts Geist: seine kurze Biographie und ästhetische Darstellung seiner Werke; ein Bildungsbuch für junge Tonkünstler (Erfurt, I803), 56 (trad. del autor).

19. "Die Krankheitsgeschichte Mozarts beweist nichts für eine Vergiftung. Sollte er durch Gift geopfert werden, so musste es auf zwey Wegen geschehen; schnell oder langsam. Schnell ist es nicht geschehen; und langsam vergiftet, hätte er — wir vollen aqua toffana nehmen- ganz andere Zufälle haben müssen”, en Arnold, Mozarts Geist, 67-68; y Nissen, Biographie W. A. Mozart's, 570-57I (trad. del autor). Agua tofana (acqua toffana): potente veneno incoloro y sin sabor de acción lenta, cuyo efecto se atribuye a causas naturales, ya que gradualmente se debilitan las fuerzas vitales. Su primera mención data del siglo XVII, cuando tuvieron lugar dos juicios por envenenamiento en Palermo, Sicilia. El primero en febrero de I632 de Francesca la Sarda; el segundo en julio de 1633 de Teofania di Adamo, de la que toma su nombre. Véase Mike Dash, "Aqua Tofan", en Philip Wexler, ed., Toxicology in the Middle Ages and Renaissance (Londres: Elsevier/Academic Press, 2017), 63-69. 
https://doi.org/10.22201/iie.18703062e.2020.117.2728

96 ARTURO GARCía GÓMEZ y OLGa CHKOURAK

textualmente la historia del Réquiem en la versión de Rochlitz, descrita como la causa de su fallecimiento. ${ }^{20}$

\section{Dramatización de la muerte de Mozart}

La mítica muerte de Mozart tuvo su repercusión en la literatura, sobre todo en piezas teatrales publicadas en Múnich, Leipzig y Graz. En febrero de I823 el dramaturgo Johan Nepomuk Adolph von Schaden (I79I-I840) publicó Das Requiem, oder Mozarts Tod, en la revista Flora de Múnich. ${ }^{21}$ En el primer acto aparecen Mozart y Schikaneder comentando sobre La flauta mágica. En el segundo charlan Mozart y un misterioso mensajero con su capa escarlata ("Mozart und der Mann im Scharlachmantel”). Sólo se publicaron dos actos. Dos años después Schaden publicó en Leipzig una versión ampliada. En la sexta escena del segundo acto, que transcurre al aire libre en el Prater, Amadeo responde al narrador: "Te digo, ¡estoy acabado!, puedo, o podría no decirte todo, la tumba está abierta a mi pena, el infierno me envía siniestros espíritus para burlarse de mí, y una maligna fiebre recorre todo mi cuerpo, jcreo que me han envenenado!"22

Simultáneamente se publicó en Graz una pequeña pieza teatral en verso, del abogado Joseph Hoffbauer, titulada: Mozart. Ein dramatisches Gedicht.23 $\mathrm{Al}$ parecer, el autor fue motivado por un artículo anónimo sobre la historia del Réquiem, publicado en la revista Der Aufmerksame de Graz, el 3I de mayo de I823, bajo el título: Mozart's letztes Werk. Eine wahre Anekdote. A manera de prólogo, Hoffbauer inicia con unos versos, seguidos de la historia del

20. Véase Louis-Alexandre-César Bombet, Lettres écrites de Vienne en Autriche sur le célèbre compositeur Jh. Haydn, suivies d'une vie de Mozart, et de considérations sur Métastase et l'état présent de la musique en France et en Italie (París: L'imprimerie de P. Didot L'Aine, I8I4), 354.

2I. Johan Nepomuk Adolph von Schaden, "Das Requiem, oder Mozart's Tod, Trauerspiel in drei Akten”, Flora. Ein Unterhaltungs Blatt, núm. 30 (viernes 2I de febrero de I823): II8-I9; y núm. 3I (domingo 23 de febrero de I823): I22-I23 (Múnich).

22. "Ich sage dir, mit mir ist's aus! ich kann, ich mag dir nicht Alles sagen, es öffnen sich zu meiner Pein die Gräber, die Hölle sendet, mich zu äffen, tückische Gespenster, ein zehrend Fieber schleicht durch meine Glieder, ich glaube, man hat mir Gift beigebracht!", en Johan Nepomuk Adolph von Schaden, Mozarts Tod, ein Original-Trauerspiel in drei Acten (Augsburgo y Leipzig, 1825), 64 (trad. del autor).

23. Joseph Hoffbauer, Mozart. Ein dramatisches Gedicht (Graz: impreso por Johann Andreas Rienreich, 1823). 
Réquiem, combinando las versiones de Niemetschek y Rochlitz. La pieza es un conglomerado de fantasías e ideales de aquellos años. ${ }^{24}$

En su poema, Hoffbauer recurre a la oposición entre italianos y germanos como impulso dramático. La idílica vida de Mozart se ve afectada por italianos sin escrúpulos; el vil Renardo y el infame Basili, que conducen al compositor a la muerte. El encargo del Réquiem es un montaje que les permite asesinar a Mozart, aunque no se especifica el contratista y se omite el envenenamiento, ya expuesto en el prólogo. ${ }^{25}$

\section{Antonio Salieri entra en escena}

Treinta y dos años después de la muerte de Mozart, el Kapellmeister y compositor de la corte de Viena, Antonio Salieri (I750-I825), entra en la escena del mito mozartiano, al ser señalado como el autor del envenenamiento de Mozart. En I820 Salieri ya mostraba visibles síntomas de locura senil. Tres años después su estado de salud se agrava. En octubre de 1823 corre el rumor de que Salieri ha muerto, y los diarios publican la falsa noticia. El 26 de octubre el diario parisino L'Étoile publica: "El célebre compositor Salieri, autor de la música de Las Danaides, murió en Viena el Io de octubre. ${ }^{26}$ Dos días después The Times y The Morning Chronicle de Londres replican la noticia.

La noticia se desmiente el i9 de noviembre en la Allgemeine Musikalische Zeitung de Leipzig: ¡La vejez es por sí misma una enfermedad! ${ }^{27}$ Ese mismo mes corre el rumor en Viena de que Salieri trató de suicidarse en el hospital donde se había recluido. No obstante, la revista musical The Harmonicon replicó en Londres la falsa noticia, ${ }^{28}$ que fue desmentida al mes siguiente por

24. Véase Ottfried Hafner, Mozart in Graz. Aspekte zur Begegnung des Komponisten mit der Stadt (Graz: Weishaupt Verlag, I99I), I3.

25. Véase Helmut C. Jacobs, "Mozart empoisonné! Extraits de la presse parisienne sur la propagation d'une rumeur au milieu des années I820", Revue de Musicologie, t. 9I, núm. 2 (2005): 459-460.

26. "Le célèbre compositeur Salieri, auteur de la musique des Danaïdes, est mort à Vienne, le io octobre", en L'Étoile, núm. III9, domingo 26 de octubre, I823, 4, consultado el I2 de mayo de 20I8, en https://gallica.bnf.fr/ark:/r2I48/bpt6k67620910/f4.item (trad. del autor).

27. "Senectus ipsa est morbus!", Allgemeine Musikalische Zeitung, núm. 47, 19 de noviembre de I823, en Jahrgang, 25 (Leipzig: Breitkopf und Härtel, I823), 766.

28. "Memoir of Antonio Salieri", The Harmonicon, A Journal of Music I, núm. II (noviembre, 1823$): 158$. 
un corresponsal vienés, la editorial argumentó que la noticia había sido tomada de diarios franceses y alemanes: "No es cierto que Salieri, como muchos diarios han anunciado, esté muerto. No obstante, la debilidad que le afecta a su avanzada edad lo mantiene totalmente inactivo. Él ha preferido refugiarse en un hospital público, que ser una carga para sus hijas solteras." ${ }^{29}$

El 23 de noviembre Anton Schindler, secretario de Ludwig van Beethoven, escribió en el cuaderno de conversaciones del compositor: "Salieri trató de cortarse la garganta, pero aún vive." ${ }^{\circ}$ En enero de I824 su sobrino, Karl van Beethoven, y Anton Schindler, anotan en el cuaderno: "Karl: Salieri afirma que él ha envenenado a Mozart.- Schindler: Salieri está otra vez muy mal. Está completamente descompuesto. Constantemente fantasea que él es el culpable de la muerte de Mozart, y que lo ha envenenado." ${ }^{31}$

En I824 el rumor de que Salieri había envenenado a Mozart se esparce por los salones de Europa. El martes i3 de abril la Académie Royale de Musique de París presentó el primer Concert spirituel de la temporada. Debutaba un tal Franz Liszt de doce años, discípulo de Antonio Salieri, y se interpretaban extractos del Réquiem de Mozart. La reseña en la prensa señalaba que antes del debut de Liszt, el rumor del envenenamiento de Mozart confesado por Salieri se propagó repentinamente por la sala. Al día siguiente, $\mathrm{I} 4$ de abril, Le Courrier français relataba:

29. "It is not true that Salieri, as many of the papers have announced, is dead. The weakness attendant on old age renders him, however, totally inactive. He has preferred to take refuge in the public hospital, rather than become an incumbrance to his unmarried daughters", en "Present State of Music in Vienna, to the Editor of the Harmonicon Vienna, December Ioth, I823", The Harmonicon, A Journal of Music II, núm. I3 (enero de I824): 3 (trad. del autor).

30. "Salieri hat sich den Hals abgeschnitten, lebt aber noch.", en Friedrich Kerst, Die Erinnerungen an Beethoven, Band 2 (Stuttgart, 1913), 282 (trad. del autor). Los cuadernos de conversación de Ludwig van Beethoven [Konversationshefte], fueron su medio de comunicación desde I8I8, debido a su sordera. Se conservan 139 cuadernos que registran el día a día de la última década del compositor. Tras su muerte, acaecida el 26 de marzo de i827, Anton Schindler (I795-I864), su secretario, conservó sus documentos, incluidos los 139 cuadernos, que utilizó en su Biographie von Ludwig van Beethoven, publicada en I840. Cuatro años más tarde Schindler vendió los cuadernos a Preußisch Königliche Bibliothek de Berlín. Véase Erwin Doernberg, "Anton Schindler", The Musical Quarterly 5I, núm. 2 (abril de 1965): 373-386.

3I. "Neffe Karl: Salieri behauptet, er habe Mozart vergiftet. —Schindler: Mit Salieri geht es wieder sehr schlecht. Er ist ganz zerrüttet. Er phantasiert stets, dass er an dem Tode Mozarts schuld sei und ihn mit Gift vergeben habe”, en Kerst, Die Erinnerungen an Beethoven, 282 (trad. del autor). 
Con los fragmentos del famoso Réquiem de Mozart terminó el concierto que ha producido una profunda impresión, a lo cual las circunstancias posiblemente han contribuido. Hace algunas semanas M. Cherubini recibió de Alemania unas cartas, en las que se insinúa que Salieri está acusado de haber envenenado a Mozart. Como el ruido ha esparcido que la vejez de Salieri ha alterado su razón, no damos importancia a esta extraordinaria noticia. Ayer aseguraron que los detalles circunstanciales a este respecto estarían llegando de Viena, y que en el momento de morir Salieri, devorado por remordimientos, ha confesado su crimen. De esta manera se explica la muerte prematura de Mozart, cuya causa aún no es del todo bien conocida. ${ }^{32}$

El jueves Is de abril, la Gazette de France retoma la noticia:

Varias salvas de aplausos recibieron un fragmento del famoso Réquiem de Mozart, muy bien dado a los artistas del teatro italiano, conjuntamente con los coros de la academia real. Antes de la obertura de este concierto, circuló en la sala, como noticia positiva, que Salieri fue acusado en su lecho de muerte de haber envenenado a Mozart ya hace tiempo, en un ataque de ¡espantosa envidia! Nosotros narramos la noticia, sin embargo, añadimos de buena fe, que desde hace mucho tiempo el autor de las Danaides estuvo tocado por una suerte de alienación mental, de la cual su revelación voluntaria no es más que el triste efecto del pasado. ${ }^{33}$

32. "Des fragments du fameux Requiem de Mozart ont terminé le concert et ont produit une impression profonde, á laquelle la circonstance suivante avait peut-être contribué. Il y a quelques semaines, M. Chérubini avait reçu d'Allemagne des lettres où l'on prétendait que Saliéri s'état accusé d'avoir empoisonné Mozart. Comme le bruit avait couru que la vieillesse de Saliéri avait altéré sa raison, on ne mit pas d'importance à cette nouvelle extraordinaire; mais hier l'on assurait que des détails circonstanciés étaient arrivés de Vienne à ce sujet, et que c'était au moment d'expirer que Saliéri, dévoré de remords, avait confessé son crime. Ainsi se trouverait expliquée la mort prématurée de Mozart, dont la cause n'avait jamais été bien connue", en Le Courrier Français, núm. I05, I4 de abril de I824, 4, citado en Jacobs, Mozart empoisonné!, 46I (trad. del autor).

33. "Plusieurs salves d'applaudissements ont accueilli un fragment du fameux Requiem de Mozart, très-bien rendu par des artistes du théâtre Italien, conjointement avec les chœurs de l'Académie royale. Avant l'ouverture de ce concert, il circulait dans la salle, comme nouvelle positive, que Salieri venait de s'accuser, au lit de mort, d'avoir jadis empoisonné Mozart dans les accès d'une épouvantable jalousie! Nous racontons la nouvelle sans néanmoins y ajouter beaucoup foi, car depuis long-tems l'auteur des Danaïdes était frappé d'une sorte d'aliénation mentale dont sa révélation volontaire n'est que le triste et dernier effet", en Gazette de France, núm. I06, Is de abril de I824, I, citado en Jacobs, Mozart empoisonné!, 46I-462 (trad. del autor). 
Ese día el Journal des Débats Politiques et Littéraires, y L'Étoile de París, publicaron un extenso artículo sobre la confesión de Salieri, citando a un anónimo corresponsal vienés.

Un diario habla hoy del envenenamiento de Mozart por Salieri, como de un hecho probado. [...] Aquí nos han enviado de Viena [...]: "Nos hemos sorprendido al leer en varios diarios de Francia, y de la misma Alemania, que Salieri se ha cortado la garganta en un hospital de Viena, donde él ha alquilado una habitación expresamente. Este anciano vivió siempre rodeado de su familia, por tanto, cuidado y querido. Pero es verdad que la edad ha alterado un poco su razón. He aquí una prueba muy singular: una de sus manías es la de dejar al margen a toda persona conocida, y de decir con una fisionomía toda risueña: "Tengo una pequeńa confidencia que hacerle; soy yo, querido amigo, quien ha envenenado a Mozart, porque estoy excesivamente celoso; pero reconozco que no tuve el menor remordimiento, ya que eso no me impide hacer muy bonitos cánones." Todo lo que él ha hecho en esta extraña confesión, no es más que un acto de demencia; y en los hechos, si, como lo ha dicho un gran poeta: "Cualquier crimen siempre precede a los grandes crímenes.” ¿Qué pasa en la vida de Salieri que poderosamente se concilia con el horror de semejante fechoría? Que él haya estado celoso del sublime autor de Don Juan, es difícil de creer. El joven Liszt, que tiene II [sic] ańos, es ya objeto de una negra envidia. Pero entre la envidia y el asesinato todavía, gracias al cielo, hay un gran intervalo que franquear. Salieri siempre pasó por tener sentimientos honestos, de costumbres dulces y además, en el fondo una gran piedad. Suponiendo que él haya cortado los días de Mozart, es un error suponer que él también haya hecho un largo estudio del veneno. Se prepara en efecto un veneno muy lento y que, hábilmente combinado por quien lo prepara, lleva a una muerte de postración. Viendo en todas las noticias consagradas a su memoria, él [Mozart] ya tenía el ataque de la enfermedad que terminó con su existencia, cuando él compuso su Flauta mágica, su Clemenza di Tito, y su famoso Réquiem, que él siempre creyó que lo había compuesto para sí mismo, según sus propias palabras. Ni él ni su esposa ni sus amigos, nunca tuvieron la idea de atribuir al veneno el fin de su extraordinaria corta carrera. Mozart pereció a los $33[s i c]$ años, un poco más joven aún que Rafael, el cual creaba de conformidad con él en un arte diferente. La causa real de la muerte prematura de estos dos extraordinarios genios, al parecer ofrece la misma deplorable similitud. El fuego 
interior que los hizo alumbrar tanto las obras maestras, también encendió en su pecho pasiones triunfantes que demasiado pronto apagaron sus fuerzas físicas. ${ }^{34}$

Al argumentar la imposibilidad real de la confesión de Salieri, el anónimo corresponsal vienés de L'Étoile rechaza la hipótesis del envenenamiento (agua tofana), mencionada por Ignaz Arnold en Mozarts Geist (I803), y se decanta por la muerte natural de Mozart, debido a su extenuante trabajo, haciendo de nuevo la comparación con el pintor Rafael que Johann Rochlitz había planteado en I798, y reafirmaría en Raphael und Mozart de I800.

34. "Un journal parle aujourd'hui de l'empoisonnement de Mozart par Salieri, comme d'un fait avéré. [...] Voici ce que nous a mandé de Vienne [...]: «Nous avons été fort étonnés de lire dans plusieurs journaux de France, et même d'Allemagne, que Salieri s'était coupé la gorge dans un hôpital de Vienne, où il avait loué une chambre tout exprès. Ce vieillard vit toujours au milieu de sa famille dont il est aussi soigné que chéri. Mais il est vrai que l'âge a un peu altéré sa raison. En voici une preuve bien singulière: une de ses manies est de tirer à l'écart toutes les personnes de sa connaissance, et de leur dire avec une physionomie toute riante: "J'ai une petite confidence à vous faire; c'est moi, mon cher, qui ai empoisonné Mozart, parce que j'en étais excessivement jaloux; mais je vous avoue que je n'en ai pas le moindre remords, puisque cela ne m'empêche pas de faire de très-jolis canons.» Tous ceux à qui il a fait cet étrange aveu, n’y ont vu qu'un acte de démence; et, dans le fait, si, comme l'a dit un grand poëte: «Quelques crimes toujours précèdent les grands crimes.» Qu'y a-t-il dans la vie entière de Salieri qui puisse se concilier avec l'horreur d'un pareil forfait? Qu'il ait été jaloux du sublime auteur de Don Juan, c'est ce qu'il n'est que trop facile de croire. Le jeune Liszt, qui n'a que II ans, est déjà l'objet d'une noire envie. Mais entre la jalousie et l'assassinat, il y a encore, grâce au ciel, un grand intervalle à franchir. Salieri à toujours passé pour avoir des sentiments honnêtes, des mœurs douces et, de plus, un grand fonds de piété. Or, pour supposer qu'il ait tranché les jours de Mozart, il faut supposer aussi qu'il avait fait une longue étude des poisons. C'eût été en effet un poison bien lent et bien habilement combiné, que celui qui eût amené la mort de langueur. On voit dans toutes les notices consacrées à sa mémoire qu’il était déjà attaqué de la maladie qui termina son existence, quand il composa sa Flûte enchantée, sa Clemenza di Tito, et ce fameux Requiem, qu'il crut toujours faire pour lui-même, selon ses propres paroles. Ni lui, ni sa femme, ni ses amis, n'eurent jamais l'idée d'attribuer au poison la fin de sa trop courte carrière. Mozart périt à 33 ans, un peu plus jeune encore que ne l'était Raphaël, avec lequel il eut tant de conformité dans un art différent. La cause réelle de la mort prématurée de ces deux génies extraordinaires, paraît offrir également cette conformité déplorable. Le feu intérieur qui leur fit enfanter tant de chefs-d'œuvre, alluma aussi dans leur sein des passions qui triomphèrent trop tôt de leurs forces physiques", en Nouvelles de la jour du I4 avril dans L'Étoile, núm. I462, jueves I5 de abril de I824, 3, consultado el I2 de mayo de 20I8, en https://gallica.bnf.fr/ark:/I2I48/bpt6k67622604/f3.itm (trad. del autor). 
$\mathrm{IO} 2$

ARTURO GARCÍA GÓMEZ Y OLGA CHKOURAK

\section{En defensa de Salieri}

Tras el rumor que lo imputaba como el asesino de Mozart, amigos y discípulos de Salieri salieron en su defensa. Su discípulo, el pianista y compositor bohemio Ignaz Moscheles (I794-I870), relata años después que en octubre de I823, con el permiso de sus hijas y autoridades, visitó a su anciano maestro en el hospital general de Alservorstadt.

Fue un encuentro triste (escribe Moscheles). Su aspecto ya me impresionó, y no hacía más que hablar, con frases entrecortadas, de su muerte inminente. Pero al final dijo: "Aunque ésta es mi última enfermedad, le aseguro bajo mi palabra de honor que no hay nada cierto en ese absurdo rumor; ya sabrá usted que dicen que yo envenené a Mozart. Pero no, es malevolencia, pura malevolencia. Cuéntele al mundo, querido Moscheles, lo que el viejo Salieri, que morirá pronto, acaba de contarle." ${ }^{35}$

El sábado 17 de abril de I824, a dos días de la reseña en la Gazette de France, y los artículos en L'Étoile y Journal des Débats Politiques et Littéraires, el compositor austriaco Sigismund Ritter von Neukomm, por medio de una carta dirigida el Is de abril a estos tres diarios, inicia la defensa pública de Salieri en Francia.

$\mathrm{Al}$ redactor. París, Is de abril de 1824. Señor, / Varios diarios han repetido que Salieri, en su lecho de muerte, se está acusando él mismo del atroz crimen de ser el autor de la muerte prematura de Mozart. Pero ninguno de estos diarios ha dado a conocer la fuente de donde sale esta horrible imputación, que consagraría a la execración la memoria de un hombre que ha gozado, durante 58 años, de la estima general de todos los habitantes de Viena. Es deber de todo hombre decir, si es que él sangra y se agita, rechazar una calumnia que mancilla la memoria de un hombre célebre. Durante mi estancia en Viena (después de 1798 hasta I804) ligué amistad con la familia de

35. "Das Wiedersehen (schreibt Moscheles), war ein trauriges; denn sein Anblick schon entsetzte mich, und er sprach mir in abgebrochenen Sätzen von seinem nahebevorstehen den Tode; zuletzt aber mit den Worten: "Obgleich dies meine letzte Krankheit ist, so kann ich doch auf Treu und Glauben versichern, dass nichts Wahres an dem absurden Gerücht ist; Sie wissen ja, - Mozart, ich soll ihn vergiftet haben. Aber nein, Bosheit, lauter Bosheit, sagen Sie es der Welt, lieber Moscheles; der alte Salieri, der bald stirbt, hat es Ihnen gesagt”, en Charlotte Moscheles, Aus Moscheles' Leben. Nach Briefen und Tagebüchern (Leipzig: Duncker und Humboldt, 1872), 84-85 (trad. de Gabriela Bustelo en Landon, I79I: El último año de Mozart, 200). 
Mozart, y es de ella que sé los más exactos detalles del pasado de este gran compositor, que está muerto como Rafael, en la flor de la vida, y no por una muerte violen$t a$, como dicen hoy, sino de una fiebre nerviosa que él se acarreó por sus inauditos esfuerzos, los cuales son para una constitución mucho más robusta que la suya, ya que su resplandor sucumbió infaliblemente. [...] Él estaba ya indispuesto desde su partida a Praga, citado a componer la ópera la Clemenza di Tito para la coronación de Leopoldo II. De regreso a Viena, él emprende la composición de su Réquiem. Debilitado por el exceso de trabajo, cae en una profunda melancolía, que Mme. Mozart decide quitarle la partitura. Esta medida y los esmeros que le prodigaron su medicina, le incita a componer su célebre cantata masónica, y que el éxito le reanima a tal punto que Mme. Mozart no pudo más rehusarse a sus peticiones de devolverle la partitura del Réquiem, que no tuvo tiempo de terminar. Pocos días después de haber reanudado el trabajo, sus accesos de melancolía se redoblaron a medida que sus fuerzas disminuían: no pudo más dejar su lecho, y en la noche del 5 de diciembre muere. Mozart tenía desde hacía tiempo una especie de presentimiento de su muerte. Me acuerdo que mi maestro Haydn me contó que, durante su primer viaje a Londres (a finales de I790), Mozart había venido a despedirse. Él le dijo abrazándolo y con los ojos repletos de lágrimas: "Me temo, papá mío, que sea ésta la última vez que nos vemos." Haydn, mucho mayor que Mozart, creyó entonces que era por su edad y los peligros del viaje, que habían inspirado a Mozart a este temor. Sin haber tenido una íntima amistad, Mozart y Salieri tenían el uno por el otro todas las consideraciones que los hombres de mérito superior les gusta rendirse mutuamente. Nunca nadie sospechó que Salieri envidiara a Mozart, y todos los que conocieron a Salieri, dirán conmigo (que lo conocí): que este hombre, que durante 58 años ha llevado bajo mis ojos la vida más irreprochable, ocupándose nada más que de su arte, y aprovechando toda ocasión para hacer el bien a sus semejantes; este hombre, digo yo, no puede ser un asesino, y conservar durante los 33 ańos que han pasado desde la muerte de Mozart, esta hilaridad de espíritu tan atractivo que le caracterizó y que devolvió a la sociedad. Cuando bien sea demostrado que el mismo Salieri, moribundo, se ha acusado él mismo de ser el autor de un horrendo crimen, no debiéramos acreditar y esparcir a la ligera, expresiones dichas en delirio de un desafortunado anciano de 74 ańos, abrumado de enfermedades que han ocasionado sufrimientos intolerables en sus facultades intelectuales y que han sido sensiblemente alteradas varios meses antes de su muerte./ Reciba Usted Señor, etc./ Sigismond Neukomm. ${ }^{36}$

36. "Au Rédacteur. Paris, le Is avril I824. Monsieur, / Plusieurs journaux out répété que Salieri, au lit de mort, s'était accusé lui-même d'un crime atroce, de celui d'avoir été l'auteur de la mort 
prématurée de Mozart; mais aucun de ces journaux m'a fait connaître la source d'où est sortie cette horrible imputation, qui vouerait à l'exécration la mémoire d'un homme qui a joui pendant 58 ans de l'estime générale de tous les habitants de Vienne. Il est du devoir de tout homme de dire ce qu'il sait personnellement, quand il s'agit de repousser une calomnie dont on veut flétrir la mémoire d'un homme célèbre. Pendant mon séjour à Vienne (depuis 1798 jusqu'en I824 [sic (I804)]) j'ai été lié d'amitié avec la famille de Mozart, et c'est d'elle que j'ai su les détails les plus exacts sur les derniers moments de ce grand compositeur, qui est mort, comme Raphaël, á la fleur de l'âge, non pas d'une mort violente, comme on nous dit aujourd'hui, mais d'une fièvre nerveuse qu'il s'était attirée par des efforts inouïs, auxquels une constitution beaucoup plus robuste que la sienne aurait succombé infailliblement. [...] Il était déjà souffrant lors de son départ pour Prague, où il était appelé pour y composer l'opéra la Clemenza di Tito, à l'occasion du couronnement de l'empereur Léopold II. A son retour à Vienne, il entreprit la composition de son Requiem. Affaibli par l'excès du travail, il fut atteint d'une mélancolie profonde, qui détermina Mme. Mozart à lui ôter sa partition. Cette mesure et les soins que lui prodiguait son médecin, le mirent en état de composer sa célèbre cantate maçonnique, dont le succès le ranima au point que Mme. Mozart ne put plus se refuser à ses instances de lui rendre sa partition du Requiem, qu’il n'a pas eu le temps d'achever. Peu de jour après s'être remis à ce travail, ses accès de mélancolie redoublèrent à mesure que ces forces diminuaient: il ne pouvait plus quitter son lit, et dans la nuit du 5 décembre, il cessa de vivre. Mozart avait depuis longtemps une espèce de pressentiment de sa mort. Je me rappelle que mon maître Haydn m’a raconté que, lors de son premier départ pour Londres (à la fi de 1790), Mozart était venu lui faire ses adieux. Il lui dit en l'embrassant, et les yeux remplis de larmes: «Mon père, je crains bien que ce ne soit pour la dernière fois que nous nous voyions.» Haydn, beaucoup plus âge que Mozart, croyait alors que c'était son âge et les dangers auxquels l'exposait son voyage, qui inspiroit à Mozart cette crainte. Sans être liés d'une amitié intime, Mozart et Salieri avaient l'un pour l'autre tous les égards [tous les égards] que des hommes d'un mérite supérieur se plaisent à se rendre mutuellement. Jamais personne n'avait soupçonné Salieri d'un sentiment de jalousie envers Mozart, et tous ceux qui ont connu Salieri, diront avec moi (qui l'ai connu); que cet homme, qui pendant 58 ans, a mené sous leurs yeux la vie la plus irréprochable, ne s'occupant que de son art, et saisissant toutes les occasions pour faire du bien a ses semblables: cet homme, dis-je, ne pouvait pas être un assassin, et conserver pendant les 33 années qui se sont écoulées depuis la mort de Mozart, cette hilarité d'esprit qui le caractérisait et qui rendait sa société si attrayante. Quand bien même il serait prouvé que Salieri, en mourant, se serait accusé lui même d'être l'auteur de ce crime affreux, on ne devrait pas si légèrement accréditer et répandre des expressions échappées au délire d'un malheureux vieillard de 74 ans, accablé d'infirmités qui lui avaient occasionné des souffrances si intolérables que ses facultés intellectuelles en étaient sensiblement altérées plusieurs mois avant sa mort”, en "Monsieur Agréez y Sigismond Neukomm", Journal des Débats Politiques et Littéraires, sábado I7 de abril de I824, 2-3. Consultado el I2 de mayo de 20I8, en https://gallica.bnf.fr/ark:/I2I48/ bpt6k4347452/f2.item (trad. del autor). La carta también se publicó en L'Étoile, núm. I464, I7 de abril de I824, 3; y la Gazette de France, núm. I08, I7 de abril de I824, 3-4. Un mes después se publicó en alemán: Sigismund Ritter von Neukomm, "Aus französische Blättern", Berliner Allgemeine Musikalische Zeitung, núm. I9, I2 de mayo de 1824, en A. B. Marx (redactor), Berliner A M 
Al final de su carta, y tras veinte años de ausencia en Viena, Neukomm reconoce como válida la falsa noticia de la muerte de Salieri, quien fallece un año después. No obstante, la publicación de esta carta no detuvo el rumor, que continuó circulando en la prensa. El lunes I9 de abril de 1824, el diario Le Corsair publicó un telegrama anónimo que decía:

- Un ruido circula en secreto desde hace algunos días en el mundo musical. El compositor Salieri, dicen, que al momento de expirar, confesó haber sido él el autor de un crimen atroz, el envenenamiento de Mozart... ¿ Tantaene animis caelestibus irae? [¿Tal ira, tal coraje hay en los Dioses?, Virgilio, La Eneida, I, II] Saliéri, ¡enemigo de Mozart y su asesino! Salieri, jamigo de Liszt y su maestro! Qué comparación extraordinaria, y ¡qué vasto tema de reflexión! ¿¿Los remordimientos lo aureolaron a buscar un heredero de los talentos de su víctima? ¿Será que los remordimientos que nos agobian son deudores de escuchar al sucesor de Mozart de nuestro tiempo? Amable niño [Liszt] que persigues tu carrera, mas el sueño de grandes deberes te son impuestos, si es que el cielo te ha destinado a suceder al más grande genio musical, el cual honra a Europa. ${ }^{37}$

Mientras el rumor recorría Europa, la noticia era publicada por corresponsales anónimos en la prensa francesa, lejos de la censura austriaca, o en la defensa abierta de Salieri como la de Neukomm. Un caso similar fue la carta inédita del conde Moritz, en respuesta al rumor esparcido el 7 de mayo de I824, durante

$Z$, Erster Jahrgang (Berlín, I824), I72. Sigismund Ritter von Neukomm (I778-1858). Compositor y pianista austriaco, discípulo de Michael y Joseph Haydn. Estudió filosofía y matemáticas en la Universidad de Salzburgo. Fue profesor de Franz Xaver Mozart. De i804 a I809 fue Kapellmeister (director de orquesta) del teatro alemán en San Petersburgo, donde dirigió el Don Giovanni de Mozart. Viajó por el norte de África y Brasil, y fue escritor de la Revue et Gazette Musicale de Paris. Véase R. Angermüller, "Sigismund Ritter von Neukomm: ein Beitrag zu seiner Biographie und seinem Verhältnis zu Wolfgang Amadeus Mozart”, MISM XX, núms. 3-4 (I972): 5-2I.

37. "- Un bruit circule sourdement depuis quelques jours dans le monde musical. Le compositeur Saliéri a, dit-on, avoué, au moment d'expirer, qu'il était l'auteur d'un crime affreux, l'empoisonnement de Mozart ... tantæne animis celestibus [sic] iræ? Saliéri, ennemi de Mozart et son meurtrie! Saliéri, ami de Liszt et son maître! Quel rapprochement extraordinaire, et quel vaste sujet de réflexions! Les remords l'auraient-ils engagé à chercher un héritier des talens de sa victime? Serait-ce aux remords que nous serions redevable d'entendre de nos jours le successeur de Mozart? Aimable enfant, poursuis ta carrière, mais songe que de grands devoirs te sont imposés, si le ciel t'a destiné à recueillir la succession du plus grand génie musical dont l'Europe s'honore.", en Le Corsair. Journal des Spectacles, de la Littérature, des Arts, des Mours et des Modes, núm. 284 (lunes I9 de abril de I824): 4, consultado al I2 de mayo de 20I8, en https:// gallica. bnf. fr/ark:/I2I48/bptbke46886575/f4.itemi824/04/19, en gallica.bnf.fr (trad. del autor). 
un concierto (Akademie) organizado por Ludwig van Beethoven en Viena para el estreno de su Novena Sinfonía y Missa solemnis. ${ }^{38}$

El rumor se propagó en una oda dedicada a Beethoven escrita por Calisto Bassi, ${ }^{39}$ que aludía, a partir de su quinta estrofa, a Salieri y al envenenamiento de Mozart en una alegoría de la "envidia" con el vaso de veneno en mano. Era la figura de un hombre vil que se identificaba con Salieri, evocando la muerte violenta de Mozart y su venganza final. El 23 de mayo el director del teatro de la corte, conde Moritz Dietrichstein-Pokau-Lesli, informa de la oda de Bassi al director de policía y censura de Viena, el conde Sedlnitzk, y exige que dé explicaciones. Al mismo tiempo, el conde Moritz envía una carta sin firmar al Journal des Débats en París, fechada el 26 de mayo de I824.

$\mathrm{Al}$ redactor del Journal des Débats/ ¡Señor!/ Hemos visto en los diarios franceses recibir una fábula que carece de todo fundamento: el pretendido envenenamiento de Mozart ipor Salieri! por Salieri, el más dulce de los hombres, y ¿por qué? por envidia. [...] Como dicen, todo el mundo sabe que Mozart ha muerto como Rafael, por haberse precipitado a vivir, a componer, y que Salieri lo lamentó más que ninguna otra persona. Por lo demás, Salieri, acabado por la edad y las enfermedades, nunca profirió en sus sentidos, ni en el delirio - y su médico lo atestigua-, que haya al menos proporcionado materia a este cuento. Así que él no cometió falta, como uno de sus amigos lo ha hecho; hay que refutar esta calumnia por el carácter consabido de Salieri, por sus setenta y cinco ańos [sic] de virtudes. Él erró al menos una vez, como en otro diario [se ha dicho], al buscar pruebas de su arrepentimiento en sus bondades por el joven Liszt. Él erró; simplemente decir que eso es falso, del todo falso. / Reciba, Señor, el testimonio de mi distinguida consideración. / uno de sus abonados / Viena en Austria 26 de mayo de I824. ${ }^{\circ}$

38. VéaseEduard Hanslick, Geschichtedes Concertwesensin Wien (Viena: Braumüller, I869), 275.

39. Calisto Bassi (s.f.-I860). Libretista y traductor. Fue director de escena del Teatro alla Scala di Milano. Su primer libreto, Il podestà di Burgos ossia il signore del villaggio, con música de Saverino Mercadante, se estrenó el 20 de noviembre de I824 en Viena. Es hijo de Luigi Bassi, célebre barítono que interpretó en 1786 al conde Almaviva en Le nozze di Figaro, y en 1787 a don Juan en Don Giovanni de Mozart.

40. "Au rédacteur du Journal des Débats/ Monsieur! / Nous avons vu avec des journaux français accueillir une fable dénuée de tout fondement: le prétendu empoisonnement de Mozart par Salieri! par Salieri, le plus doux des hommes, et pourquoi? par jalousie. [...]. Comme que ce soit, tout le monde sait ici, que Mozart est mort comme Raphaèl, pour avoir été aussi pressé de vivre, que de composer, et que, regretté généralement, il ne l'a été par personne plus que par Salieri. Au surplus, Salieri, accablé par l'âge et par les infirmités, n’a jamais, ni dans 
Ese mismo año el escritor Giuseppe Carpani ${ }^{41}$ publicó una extensa carta en defensa de Salieri, fechada el Io de agosto de I824 en Viena, y dirigida al editor del Giornale di Letteratura, Scienze ed Arti de Milán, Giuseppe Acerbi. Carpani escribe:

Se acusa al maestro Salieri nada más que de haber preparado un veneno, dando muerte al celebérrimo Mozart [...] Pero qué responden los detractores perversos: ¿Mozart fue envenenado? ¿Sí? ¿Dónde están las pruebas? [...]. Es inútil preguntarlo. No hay pruebas y además es imposible encontrarlas, porque Mozart contrajo fiebre reumática infecciosa que no sólo le atacó a él, sino que aniquiló a todos aquellos que la contrajeron durante aquellos días. Los esfuerzos y la experiencia de los profesores de medicina más famosos, Closset y Sallaba, resultaron inútiles, inútiles también las lágrimas de los hijos, los rezos de la esposa y las esperanzas de toda la ciudad de Viena para el amado maestro. ${ }^{42}$

son bon sens, ni dans le déliré- et son médecin l'atteste — rien proféré qui ait pu le moins du monde fournir matière à ce conte. Il ne faut donc pas, comme un de ses amis l'a fait, chercher à réfuter cette calomnie par le caractère connu de Salieri, par soixante et quinze ans de vertus ; il faut encore moins, comme dans une autre journal, chercher une preuve de son repentir dans ses bontés pour le jeune Liszt. Il faut tout simplement dire que cela est faux, de toute fausseté. Recevez, Monsieur, l'assurance de ma considération distinguée. / un de vos abonnés / Vienne en Autriche le 26 Mai 1824", en "Unbekannt an den Redakteur des Journal des Débats in Paris, Wien, 26. Mai I824", Mozart Briefe und Dokumente, consultado el is de mayo de 20I8, en http://dme.mozarteum.at/DME/briefe/letter.php?mid=72\&cat] (trad. del autor). La carta nunca se publicó en el Journal des Débats. G. Nikolaus von Nissen la recopiló para el archivo epistolar [Kollektaneen] de su Biographie W. A. Mozarts nach Originalbriefen. Véase Gustav Gugitz "Zu Mozarts Tod”, Mozarteum-Mitteilungen III, núm. I (I920): 6; Rudolph Angermüller, "Nissen Kollektaneen für seine Mozartbiographie", Mozart-Jahrbuch 197I-1972 (Salzburgo: Bärenreiter, 1973), 224-25; y Jacobs, Mozart empoisonné!, 465-466.

4I. Giuseppe Carpani (1752-I825). Escritor, libretista y traductor italiano. De 1792 a 1796 fue editor de la Gazzetta di Milano. Sus sentimientos antifranceses lo forzaron a mudarse a Viena durante la ocupación francesa de Lombardía. Fue pensionado por la corte austriaca como libretista y crítico musical. Hoy es reconocido como el autor de la biografía de Haydn: Le Haydine, ovvero Lettere su la vita e le opere del celebre maestro Giuseppe Haydn (Milán, I8I2), plagiada por Henri Beyle (Stendhal). Véase supra n. 20 y Vernon Gotwals, "The Earliest Biographies of Haydn", The Musical Quarterly, XLV (1959): 439-59.

42. "Si accusa il maestro Salieri di niente meno che d'avere mercé d'un veleno apprestatogli, data morte al celeberrimo Mozart [...] Che però rispondete, o detrattori scellerati: il Mozart fu morto de un veleno? Si? Dove sono le prove? [...] Non ve ne hanno, ne possibile saria che ve ne fossero, perché in Mozart fu rapito d una febbre infiammatoria reumatica che tolse di vita con lui quasi tutti que' che ne furono attaccati a que' giorni. Vano andò lo zelo e la perizia dei due celebri professori di medicina Closset e Sallabà; vano il pianto de' figli, il pregar della sposa, e vani i voti di tutta Vienna pel suo prediletto maestro", en Giuseppe Carpani, "Lettera del 
Lo escrito por Carpani, lúcido y lleno de argumentaciones, afirma Gualtiero Boaglio, representa el último ejemplo de su voluntad (enfermo y al final de su carrera) por estar siempre presente en la polémica y el debate sobre el arte de su época en Viena.

Carpani vive en este clima de voces difamatorias, aunque no sufre las consecuencias directas como "italiano", y decide reaccionar no sólo por amor a la justicia, sino sobre todo, por celebrar al último gran representante del "siglo de oro" de la "italianidad" en Viena. Carpani ve presente en Salieri los valores del Settecento italiano, e insiste ahora en concebir "ideales" que apoyen la nueva situación, sea musical o literaria, proveniente del mundo germano, a tiempo conveniente de reconquistar la superioridad de los italianos en Viena. ${ }^{43}$

En efecto, por más de doscientos años, desde el retorno a la monodia acompańada del "recitar cantando" florentino, como reacción a la "barbarie gótica" de la polifonía flamenca, ${ }^{44}$ los italianos habían dominado la escena operística, y de San Petersburgo a Madrid se disputaban las capitales europeas. En el siglo XIX compositores, libretistas, cantantes, directores, empresarios y músicos italianos dominaron la escena operística incluso en América, aunque ya no de manera hegemónica. ${ }^{45}$

sig. G. Carpani in difesa del M. ${ }^{\circ}$ Salieri calunniato dell'avvelenamento del M.o Mozzard”, en Giuseppe Acerbi, dir. y ed., Biblioteca Italiana ossia Giornale di Letteratura, Scienze ed Arti, t. XXXV (Milán, I824), 264-265 (trad. del autor y de Gabriela Bustelo en Landon, I79I: El último año de Mozart, 20I).

43. "Carpani vive in questo clima de voci diffamanti, ne subisce forse anche le conseguenze dirette come»italiano", e decide di reagire non solo per amor di giustizia ma soprattutto per celebrare l'ultimo grande rappresentante del»seco d'oro«dell'»italianità«a Vienna. Carpani vede presenti in Salieri i valori del Settecento italiano, che egli si ostina a concepire ancora»ideali«, da opporre alle istanze nuove, sia musicali che letterarie, provenienti dal mondo tedesco e già in atto di prendere il sopravvento su quelle italiane a Viena", en Gualtiero Boaglio, "L'ameno Salieri e il virtuoso Mozart, Riflessioni intorno ad una lettera di Giuseppe Carpani”, Studien zur Musikwissenschaft, núm. 40 (199I): 25 (trad. del autor).

44. Véase Vincenzo Galilei, Dialogo della musica antica et della moderna (Florencia: Apreffo Giorgio Marelcotti, I58I); y Enrico Fubini, La estética musical desde la Antigüedad hasta el siglo $X X$ (Madrid: Alianza Editorial, 2000), I39-I42.

45. Véase Arturo García Gómez, "Nacionalismo e identidad musical en el México independiente. De Catalina de Guisa a Guatimotzin", Ciencia Nicolaita, Revista de la Universidad Michoacana de San Nicolás de Hidalgo, núm. 72 (diciembre de 2017): 7-32. 
Su ocaso inició con el nacionalismo romántico que surge de la concepción antiilustrada del lenguaje y la historia, en la obra de Johann Gottfried Herder: Auch eine Philosophie der Geschichte zur Bildung der Menschheit (1774). Herder fue discípulo de Kant y formó parte de los Stürmer, al ser el primer filósofo con sentido histórico en Alemania. Su concepción del desarrollo histórico era profundamente novedosa. El arte, los gustos y costumbres de cada pueblo debían ser valorados desde la perspectiva del pueblo y su época, y no desde cánones eternos de formas artísticas, característicos del pensamiento ilustrado.

Herder revalora al pueblo, que contrapone a la noción ilustrada del Estado y a los criterios culturales absolutos del cosmopolitismo. ${ }^{46}$ La relación romántica entre lengua y nación se reflejó de inmediato en el arte, y aun antes de Herder apareció en Austria el Nationaltheater de piezas interpretadas en lengua vernácula, Das deutsche Singspiel, que sirvió de ejemplo a Mozart en Die Entführung aus dem Serail (I782) y en Die Zauberflöte (I79I).

En este nuevo clima cultural del siglo XIX, las cartas en defensa de Salieri no surtieron efecto alguno en la opinión del público. Al ser el compositor predilecto de la corte de José II, Salieri tuvo suficientes razones para estar celoso de Mozart, y fue efectivamente el autor de innumerables intrigas en la última década de su vida. Pero 33 años después, Salieri sólo representaba el glorioso pasado del predominio italiano en la corte, y su obra poco a poco desapareció de la escena, eclipsada por la grandiosa obra de Mozart. Por ello, con la supuesta confesión al final de su vida, Salieri se convirtió en el chivo expiatorio perfecto del sentimiento nacionalista germano, como causante de la muerte prematura del gran genio; el criminal que suministró incluso un veneno "siciliano", el acqua toffana.

$\mathrm{El} 7$ de mayo de 1825 Salieri fallece en Viena. ${ }^{47}$ Días después Karl van Beethoven anota en el cuaderno de conversaciones de su tío: "Se puede decir ahora muy fuerte, que Salieri es el asesino de Mozart." ${ }^{8}$ Su estigma pasaba a la historia. En 1854 Henry Chorley escribe en Modern German Music: "Salieri, [...] siempre estuvo bajo el estigma de interponerse en el camino de Mozart,

46. Véase Giovanni Reale, Historia del pensamiento filosófico y científico, trad. Juan Andrés Iglesias, t. 3 (Barcelona: Editorial Herder, 1995), 59-6I.

47. Véase Johann Rochlitz, "Nekrolog. Antonio Salieri", Allgemeine Musikalische Zeitung, núm. 24, I5 de junio de I825, Jahrgang 27 (Leipzig: Breitkopf und Härtel, I825), 408-4I4.

48. "Neffe Karl: Man sagt auch jetzt sehr stark, dass Salieri Mozarts Mörder ist", en Kerst, Die Erinnerungen an Beethoven, 283 (trad. del autor). 
incluso a tal punto de ser salvajemente acusado de administrar el aqua tofana al compositor del 'Don Juan'." 49

Al parecer, la principal instigadora del rumor del envenenamiento de Mozart fue su propia viuda. En 1828 Constanze Maria von Nissen (viuda de Mozart) publicó en Leipzig la cuarta biografía de Mozart, escrita por su difunto segundo esposo, el diplomático danés Georg Nikolaus von Nissen, en la que por tercera ocasión se citaba la famosa anécdota del Prater..$^{50} \mathrm{Al}$ año siguiente, en una carta fechada en Salzburgo el i4 de julio de i829, Constanze Maria responde a la propuesta del compositor y editor inglés Vincent Novello y su esposa Mary, en su intención de saber de viva voz sobre la familia Mozart. ${ }^{51}$

Ese año, en Salzburgo, Constanze relata a los Novello la famosa anécdota del Prater, agregando el detalle del agua tofana mencionado por Ignaz Arnold en I803: "Como seis meses antes de su muerte, él estaba poseído con la idea de su envenenamiento - 'Sé que voy a morir', dijo, 'alguien me ha dado agua tofana y ha calculado el momento preciso de mi muerte - por ello han pedido un réquiem, que estoy escribiendo para mí mismo." ${ }_{52}$

49. "Salieri, $[\ldots]$ who has always laid under the stigma of having stood in Mozart's way — to the point even of his being wildly accused of having caused the administration of aqua tofana to the composer of 'Don Juan'”, en Henry Fothergill Chorley, Modern German Music, vol. II (Londres: Smith, Elder, I854), I93 (trad. del autor).

50. Véase Nissen, Biographie W. A. Mozart's, 563.

5I. "Monsieur! / Ma bellesoeur, se trouvant depuis quelques mois, dans un etat si déplorable, en ce qui concerne sa santé, c'est à moi, qu'elle a remis les lettres que Vous avez bien eu la bonté de lui apporter. C n'est qu'avec le plus grand plaisir, que je ferai la connaissance d'un admirateur si zelé, de feu mon mari, que Vous Monsieur, et si Vous voulez Vous donner la peine, de venir me trouver, j'aurai l'honneur de Vous attendre chez moi, cet apris dinné, ou je Vous remercirai de vive voix, de l'interet, que Vous prenez à la famille de Mozart. / Sur le Nonnenberg No 23. /A Monsieur Novello. célebre artiste", en "Constanze Nissen an Vincent Novello in Salzburg, Salzburg, I4. Juli I829", Mozart Briefe und Dokumente, consultado el 5 de mayo de 20I8, en http://dme.mozarteum.at/DME/briefe/letter.php?mid=IO4\&cat.

52. "Some six months before his death he was possessed with the idea of his being poisoned - 'I know I must die', he exclaimed, 'some has given me acqua toffana and has calculated the precise time of my death - for which they have ordered a Requiem, it is for myself I am writing this'”, en Nerina Medici, comp., Rosemary Hughes, ed., A Mozart Pilgrimage: being the Travel Diaries of Vincent \& Mary Novello in the Year 1829 (Londres: Novello, 1955), I25 (trad. del autor). Esta última mención de la anécdota del Prater no tuvo efecto alguno en la ya deteriorada imagen de Salieri, ya que vio la luz hasta 1955, cuando el diario de viaje fue publicado en Londres. Curiosamente, se ha descubierto en tiempo reciente gran cantidad de arsénico en la tinta del manuscrito de Die Zauberflöte, principal ingrediente del agua tofana. Véase Claudia Zenck (con Oliver Hahn), "Die Tinten des Zauberflöten-Autographs. Möglichkeiten und Grenzen 


\section{Mozart y Salieri de Pushkin}

En I832 se publicó en San Petersburgo Моиарт и Сальери [Mozart y Salieri], del poeta Alexander Serguéyevich Pushkin (I799-1837), tercera obra teatral inspirada en la leyenda de Mozart. El tema central es la envidia, que el poeta ruso describe en la pasión que somete a Salieri para cometer un terrible crimen, el envenenamiento de Mozart. Ésta fue la segunda de cuatro "escenas dramáticas", o "pequeñas tragedias", que el poeta escribió en el otońo de I830, conocido como el Primer otoño de Boldino. ${ }^{53}$

El 9 de diciembre de 1830 Pushkin escribe a su amigo Pëtr Alexandrovich Pletnëv (I792-I865): "Te digo (en secreto) que en Boldino he escrito como hace mucho no lo hacía. He aquí lo que traje: [...] Varias escenas dramáticas, o pequeñas tragedias, que son: El avaro caballero, Mozart y Salieri, Banquete durante la peste, y Don Juan." ${ }_{4}$

Mozart y Salieri se publicó por vez primera el 24 de diciembre de i83I para el almanaque Flores del Norte de San Petersburgo. 5 Al año siguiente se incluyó en la colección Poemas de "Flores del Norte" del año $1832 .{ }^{56}$ La pieza está fechada el 26 de octubre de i830. El manuscrito se ha perdido, no obstante se

neuer Analyseverfahren. Ein Nachtrag zur Chronologie und eine biographische Pointe", Acta Mozartiana 50, cuaderno I/2 (2003): 3-22.

53. Первая Болдинская осень - En el otoño de i830, debido a una alerta de cólera en Moscú, Pushkin se ve obligado a permanecer en su finca Bolshoe Boldino [Большое Болдино], ubicada en la región de Nizhnegorod [Нижегородская губерния]. Durante la cuarentena, y en espera de su boda con Natalia Koncharovaja, Pushkin escribió una considerable cantidad de obras, siendo una época muy productiva. Véase «Несколько словъ о Холере» Московский Вестникъ. Часть Четвертая, 1830, 323-324 [“Sobre el cólera”, El Mensajero Moscovita, núm. 4 (I830): 323-324].

54. “Скажу тебе (за тайну) что я в Болдине писал, как давно уже не писал. Вот что я привёз сюда: [...] Несколько драматических сцен, или маленьких трагедий, именно: «Скупой Рыцарь», «Моцарт и Сальери», «Пир во время чумы», и «Дон-Жуан»," en А. С. Пушкин. Письмо 374. П. А. Плетневу. 9 декабря І8зо г. Из Москвы в Петербург // Собрание сочинений в десяти томах. Том девятый. Письма І815-1830 годов. Москва «Художественная литература», 1977, 354 [A. S. Pushkin. "Carta 374. a P. A. Pletnëv, 9 de diciembre de I830. De Moscú a St. Petersburgo", en Obra reunida en diez tomos, t. 9 Cartas I8I5-I830 (Moscú: Literatura Artística, 1977), 354 (trad. del autor).

55. А. С. Пушкин. "Моцарт и Сальери” в: Северные изветы на I832 годь. Санктпетербург, I831, I7-32 (A. S. Pushkin. "Mozart y Salieri”, en Flores del Norte de I832 [San Petersburgo, I83I], I7-32).

56. А. С. Пушкин. “Моцарт и Сальери” в: Стихотворения (Изъ Севверныхъ Цветовъ I832 года). Санктпетербургъ 1832, I-I2 [A. S. Pushkin, "Mozart y Salieri”, en Poemas (De Flores del Norte del año I832) (San Petersburgo, I832), I-I2. 
conserva su carpeta que lleva por título: 3aвucms [Envidia]. De hecho, cada una de estas cuatro 'pequeñas tragedias' está dedicada a un pecado capital: avaricia, envidia, gula y lujuria, respectivamente.

Los temas de las piezas son extranjeros, alejados de la política rusa del momento, los 'decembristas'. En ellas Pushkin se aparta del "drama histórico" shakesperiano (Boris Godunov), y pasa del "destino del pueblo" al "destino de la humanidad". En lugar del drama histórico, desarrolla el momento dramático aislado, enfocado a la representación de las "pasiones" en forma simple y lacónica, que toma como modelo de las Dramatic Scenes del poeta inglés Barry Cornwall, ${ }^{57}$ quien escribe: "El objetivo que he tenido en mente, cuando escribí estas 'escenas', fue probar su efecto en un estilo más natural, que el que por mucho tiempo ha prevalecido en nuestra literatura dramática." 58

Pushkin crea una breve y lacónica escena dramática, como el rumor mismo, que consta de dos escenas: la alcoba de Salieri, con 156 líneas; y la taberna $E l$ León de Oro, con 75 líneas; ambas en verso pentámetro yámbico (shakesperiano). Intervienen sólo dos personajes: Salieri, el personaje principal; y Mozart, la víctima. La obra inicia con un monólogo de Salieri de 66 líneas, en las que expone su formación, sus ideas estéticas y su envidia por Mozart. Jovial y alegre entra Mozart a escena acompañado de un violinista ciego, en contraste con la amargura de Salieri. La escena culmina con un segundo monólogo de Salieri, en el que asume su destino y decide envenenar a Mozart. En la segunda escena Mozart y Salieri conversan a la mesa en la taberna El León de Oro. Mozart está triste y relata a Salieri el famoso episodio del Réquiem. Salieri lo anima y arroja el veneno en su copa. Brindan, y Mozart toca un fragmento del Réquiem. Salieri llora de emoción. Mozart se siente mal y se despide. La escena culmina con la duda de Salieri sobre su propia genialidad.

57. Véase М. П. Алексеев. Моцарт и Сальери [Комментарий]// А. С. Пушкин. Полное собрание сочинений. т. 7. Драматические произведения [Л.], АН СССР, 1935, 380 [М. Р. Alekseev. "Mozart y Salieri (comentarios)", en A. S. Pushkin, Obra completa. t. 7, Obras dramáticas (Leningrado: Academia de Ciencias URSS, 1935), 380.

58. "One object that I had in view, when I wrote these 'Scenes', was to try the effect of a more natural style than that which has for a long time prevailed in our dramatic literature", en Barry Cornwall, "The Poetical Works of Barry Cornwall. Dramatic Scenes", en The Poetical Works of Milman, Bowles, Wilson and Barry Cornwall (París: A \& W Galignani, I829), I. Un ejemplar de esta obra se encuentra en la Casa de Pushkin de la Academia de Ciencias. Véase Д. П. Якубович. Книга из библиотеки Пушкина „Известия ЦИК“, 1934, № 240 (D. P. Yakubovich, “Un libro de la biblioteca de Pushkin”, Izvestija CIK, núm. 240 [1934]). 
I. Salieri en su alcoba.

Dibujo de Mikhail Vrubel, i884. Tomado de Моцарт и Сальери (Петроградъ: Общины Св. Евгеніи, I917; edición facsímil [Leningrado: Aurora Art Publishers, I988]), I2.

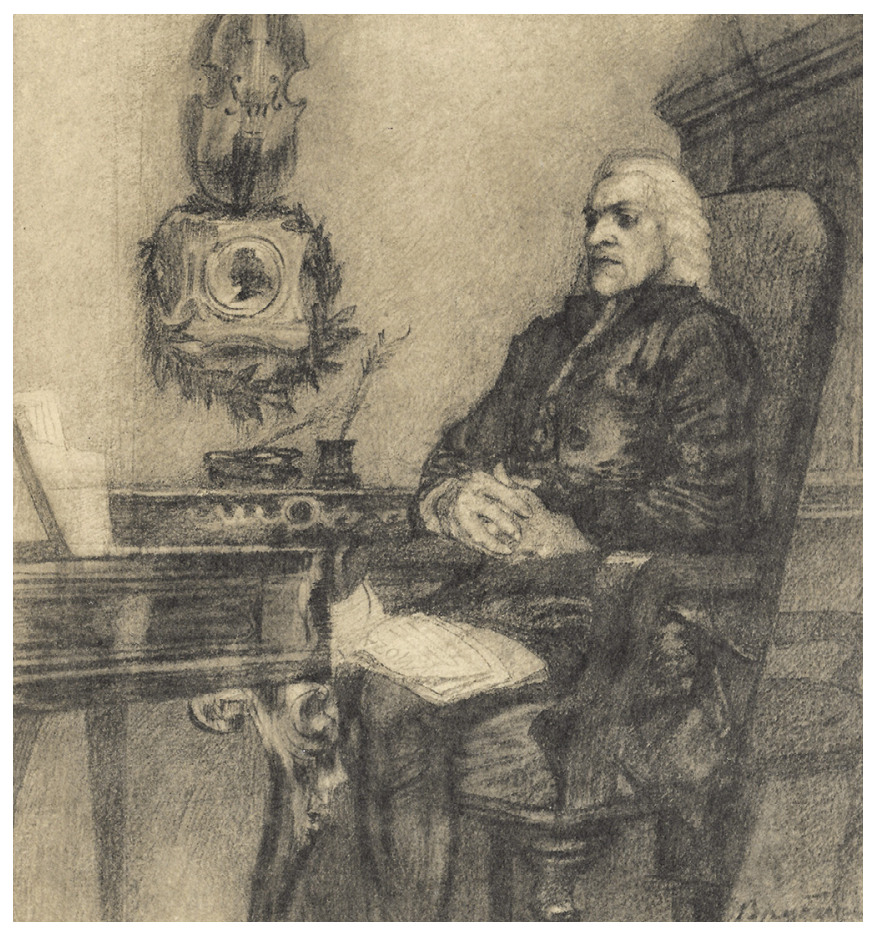

Fuentes de inspiración de Pushkin

La obra de Pushkin es muestra fehaciente de la enorme popularidad alcanzada por el mito romántico del genio creador, llegando el rumor del envenenamiento de Mozart hasta los confines de Europa; un binomio perfecto para la dramatización de su muerte. Por la característica de sus fuentes, Mozart y Salieri se asemeja en el plano pictórico a la obra de Théodore Géricault, Le Radeau de la Méduse (I819), quien con base en noticias periodísticas del naufragio de la fragata Méduse de la marina francesa, encallada frente a las costas de Mauritania el 2 de julio de i8I6, concibe su gran obra pictórica.

No se tienen testimonios fidedignos que indiquen las fuentes exactas de inspiración de Pushkin, aunque existen suficientes indicios sobre su concepción en la obra misma. En I832 Pushkin escribió al reverso de unas notas de su amigo Nikolai M. Smirnov: 


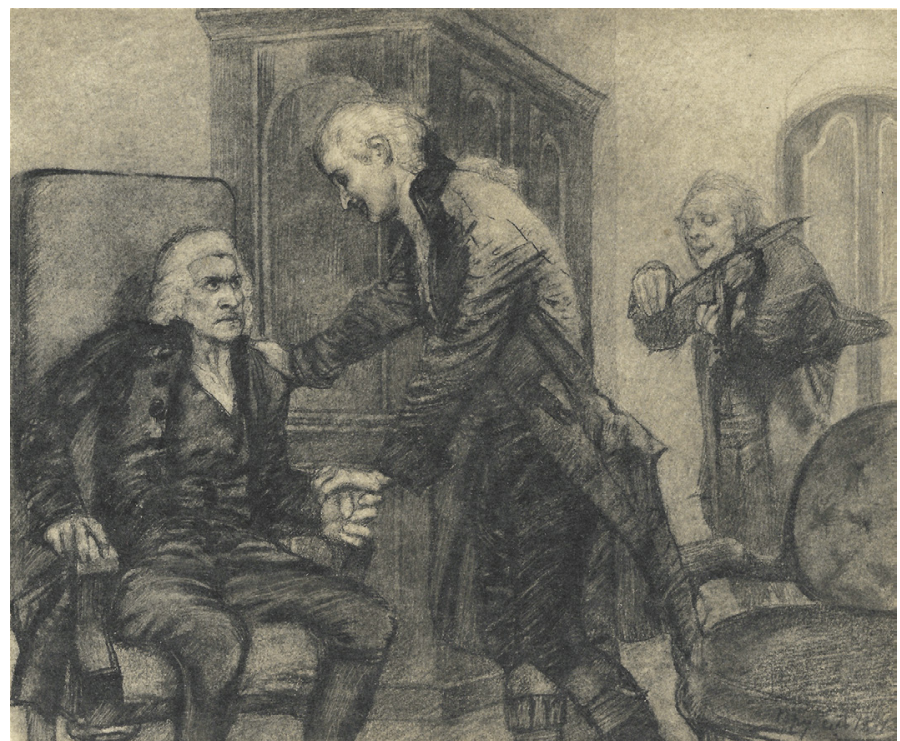

2. Mozart y Salieri escuchan al violinista ciego. Dibujo de Mikhail Vrubel, I884. Tomado de Моцарт и Сальери (Петроградъ: Общины Св. Евгеніи, 1917; edición facsímil [Leningrado: Aurora Art Publishers, 1988]), I5.

En la primera representación de "Don Giovanni”, cuando todo el teatro estaba lleno de sorprendidos conocedores que silenciosamente se embriagaban de la armonía de Mozart, se oyó un silbido - todos se voltearon con indignación, y el célebre Salieri salía de la sala enloquecido de bucólica envidia. Salieri murió hace ocho años. Algunos diarios alemanes dijeron que en su lecho de muerte confesó haber cometido un terrible crimen, el envenenamiento de Mozart. El envidioso que pudo chiflar al "Don Giovanni", también pudo envenenar a su creador. 99

59. “О Сальери. В первое представление «Дон Жуана», в то время когда весь театр, полный изумленных знатоков, безмолвно упивался гармоней Моцарта, раздался свист - все обратились с негодованием, и знаменитый Сальери вышел из залы - в бешенстве, снедаемый завистию. Сальери умер лет 8 тому назад. Некоторые немецкие журналы говорили, что на одре смети приснался он будто бы в ужсном преступлении - в отравлении великого Моцарта. Завистник, который мог освистать «Дон Жуана», мог отравить его творца.» в А. С. Пушкин. О Сальери // Собрание сочинений в десяти томах. Том шестой. Критика и публицистика. Москва “Художественная литература» 1975, 333 [А. S. Pushkin, “Sobre Salieri”, en Obra reunida en diez tomos, t. 6, Crítica y publicística (Moscú: Literatura Artística, 1975), 333] (trad. del autor). 


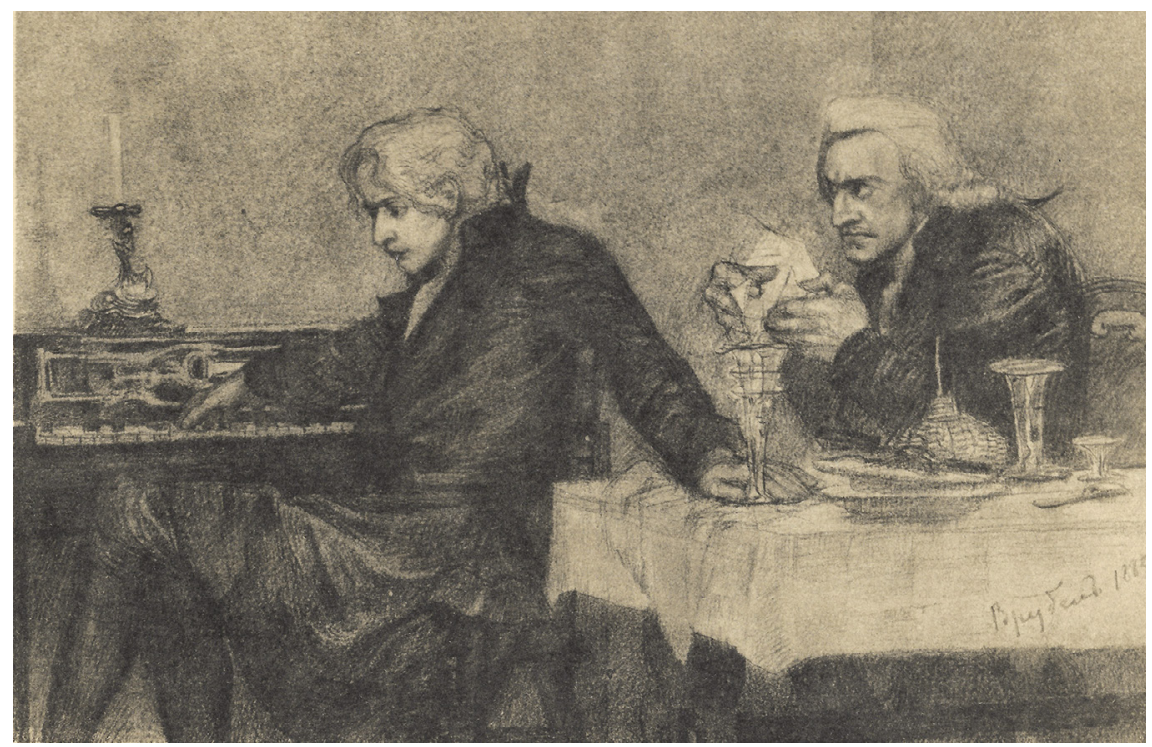

3. Salieri arroja el veneno a la copa de Mozart. Dibujo de Mikhail Vrubel, i884. Tomado de Моцарт и Сальери (Петроградъ: Общины Св. Евгеніи, 1917; edición facsímil [Leningrado: Aurora Art Publishers, 1988]), 23.

Según el diario del escritor Mikhail Petrovich Pogodin, amigo de Pushkin y editor del Московский Вестник [Mensajero Moscovita], la concepción de Mozart y Salieri data de 1826, durante su reclusión en Mijáilovskoye. ${ }^{60}$ Pero es posible que se remonte a I824, hacia el final de su servicio militar en Odesa, coincidiendo con la publicación de los rumores del envenenamiento de Mozart en Francia. ${ }^{61}$ Antes de abandonar Odesa, Pushkin debió advertir las noticias

6о. Пушкин по документам Погодинского архива // Пушкин $u$ его современники: Материаль и исследования / Имп. акад. наук. Пг., I9I4. Вып. I9/20, 73 ["Pushkin en documentos del archivo de Pogodin", en Pushkin y sus contemporáneos: Materiales e investigación (Praga: Academia Imperial de Ciencias. vol. I9/20 (I9I4): 73)]. Mijáilovskoye [Михайловское]: finca de Nadezhda Osipovna, madre de Pushkin, en la región de Pskov, donde permaneció recluido de I824 a I826, acusado de ateísmo por el emperador, debido a su texto: Воображаемьй разговор с Александром I [Charla imaginaria con Alexander I].

6I. En I824 el tiraje de la Gazette de France, L'Étoile y Le Courrier français eran similares: 2,300; 2,794; y 2,975 ejemplares respectivamente; a diferencia del Journal des Débats Politiques et Littéraires, con I3,00o ejemplares. Véase Charles Ledré, La Presse à l'assaut de la monarchie I8I5-I848 (París: Colin, I960), 242. 
sobre la confesión de Salieri y la carta de Neukomm en el Journal des Débats del jueves 15 y sábado 17 de abril de I824. La posibilidad de esta fuente es evidente, ya que Pushkin menciona en su obra al pintor Rafael Sanzio, que Rochlitz y Neukomm comparaban con Mozart, cuando Salieri dice: "No me es gracioso cuando un mal pintor mancha a la Madona de Rafael". ${ }^{62}$

Además de las noticias periodísticas, es posible que tras su reclusión en Mijáilovskoye, Pushkin haya escuchado de viva voz el rumor en intermedios teatrales y conversaciones de salón en San Petersburgo y Moscú, en su contacto directo con los círculos musicales y literarios de la época. ${ }^{63}$ Entre el público asiduo a estos salones se encontraba el príncipe Nikolai Golitsïn [Голицын], violoncellista amigo de Pushkin, quien comisionó tres cuartetos a Beethoven, coincidiendo con la propagación del rumor en Viena. ${ }^{64}$

La confesión de Salieri bien pudo esparcirse entre el público moscovita y de San Petersburgo, pues en ese momento surgía en Rusia una germanofilia romántica, y un verdadero culto a Mozart, que inició con la publicación del Libro de bolsillo para amantes de la música de 1795, con una breve biografía de Mozart (Schlichtegroll I79I). ${ }^{65} \mathrm{Al}$ año siguiente (1796) se representaba en San Petersburgo por vez primera Die Zauberflöte de Mozart. ${ }^{66}$

En enero de 1825, el Telégrafo Moscovita publicó en su primer número una noticia que decía: "como de costumbre el teatro italiano alegró a los

62. “Мне не смешно, когда маляр негодный Мне пачкает Мадонну Рафаэля” в А. С. Пушкин. Моцарт и Сальери // Собрание сочинений в десяти томах. Том четвертый. Евгений Онегин. Драматические произведения. Москва «Художественная литература» 1975, 279-287. Сцена I, 8I-83 [A. S. Pushkin. "Mozart y Salieri”, en Obra reunida en diez tomos, t. 4. Evgeni Onegin. Obras dramáticas (Moscú: Literatura Artística, 1975), 279-287, escena I, 8I-82] (trad. del autor. Véase anexo I).

63. Véase Пуикин, Полное собрание сочинений [1935], t. 7, 526 (Pushkin, Obra completa, t. 7, 526 [1935]).

64. Golitsïn comisionó los cuartetos: op. I27 E b -Dur (I824); op. I32 a-moll (I825); y op. I3O B b-Dur (I826). El 7 de abril de I824 Golitsïn estrena la Missa solemnis op. I23 de Beethoven en San Petersburgo.

65. И. Д. Герстенберг (издатель). Карманная книга для любителей музыки на I795 г. СПБ. Отдел рукописей научной музыкальной библиотеки Санкт-Петербургской консерватории имени Н. А Римского Корсакова [I. D. Gerstenberg, ed., Libro de bolsillo para amantes de la música de 1795. SPb. Sección de manuscritos de la Biblioteca del Conservatorio de San Petersburgo, N. A. Rimsky-Korsakov].

66. Véase Моцартъ въ России // Русская музыкальная газета № 3, 15 января 1906 г. с. 66-8I, en Моцартъ въ России // Русская музыкальная газета № 3, I5 января 1906 г. с. 66-8г [“Mozart en Rusia”, Revista Musical Rusa, núm. 3 (Is de enero de 1906): 66-8I] . 
celosos seguidores de Rossini ¿pero creerán nuestros descendientes, cuando les digamos que en el transcurso de cuatro años de permanencia de la compañía, ni una sola ópera de Mozart ha sido representada en el teatro italiano?" 67

$\mathrm{Al}$ mes siguiente se escenificaba en Moscú Don Giovanni de Mozart, y la misma revista reseñaba sobre la división de los melómanos moscovitas en dos bandos: "'mozartianos' y 'rossinianos' [...] En el mundo espiritual hay dos clases de genios: unos nacen para todos los siglos y para todos los pueblos, alcanzando la esencia del arte: otros nada más son genios, sólo por aparecer en el momento oportuno, de acuerdo a su propio espíritu... Mozart pertenece al primer tipo de genios, Rossini al segundo". ${ }^{68}$

El autor de este artículo, Alexandre Dimitrievich Oulibicheff (I794-1858), fue uno de los primeros críticos musicales en Rusia, y compartió con Pushkin los círculos literarios de la época, como la sociedad aristocrática de escritores llamada simbólicamente Зелёная тампа [Lámpara verde]. El ambiente musical de Moscú y San Petersburgo descrito por Oulibicheff, tanto en el Telégrafo Moscovita como en el Journal de St. Pétersbourg Politique et Littéraire, ${ }^{69}$ nos ilustra sobre la posibilidad de que el rumor de la horrible confesión de Salieri asimismo haya recorrido los salones en Rusia.

También es probable que Pushkin tuviera conocimiento de las piezas teatrales sobre la muerte de Mozart, escritas previamente en I823 por Schaden y Hoffbauer, ya que a juzgar por los subtítulos listados en la carpeta del manuscrito que se conserva, Pushkin pretendió inicialmente presentar su obra como

67. «итальянский театр попрежнему составлял отраду ревностных почитателей Россини ... но поверят ли наши потомки, когда мы скажем, что в продолжении четырёхлетнего здесь пребывания труппы ни одна Моцартова опера не была играна на итальянском театре?» в: Московский Телеграф, № I, январь I825, 4-5 [Telégrafo Moscovita, núm. I (enero de I825): 4-5] (trad. del autor).

68. “„моцартистов“ и „россинистов“ [...] В мире нравственном два рода гениев: одни родятся для всех веков, для всех народов и постигают сущность искусства: другие потому только гении, что являются во время, сообразно с их собственным духом...Моцарт принадлежит к первому роду гениев, Россини ко второму.» в: А. Д. Улыбышев „О музыке в Москве и московских концертах в І825 г.“ // Московский Телеграб, № 4, февраль І825, 62-67 [A. D. Oulibicheff, "Sobre la música en Moscú y los conciertos moskovitas en I825”, Telégrafo Moscovita, núm. 4 (febrero de I825), 62-67] (trad. del autor).

69. El mismo artículo de Telégrafo Moscovita se publicó en francés en el Journal de St. Pétersbourg Politique et Littéraire, núm. 25 (I825): II3-II6, titulado: "Les deux partis en musique". De I8I2 a I830, Oulibicheff fue redactor del Journal de St. Pétersbourg Politique et Littéraire, en donde replicó en el núm. 8 de enero de I826 (30), la noticia sobre la muerte de Salieri. 
una traducción anónima del alemán, para eludir así la crítica y la censura por la mistificación de un rumor no comprobado. Otra fuente de inspiración para su "pequeńa tragedia" fue la historia del Réquiem y su incógnito contratista, conocida en Rusia a través de Oulibicheff, que publicó en el número 48 del Journal de St. Pétersbourg Politique et Littéraire de 1826. En la tragedia de Pushkin, Mozart describe al incógnito contratista como "el hombre de negro":

Un hombre vestido de negro con reverencia cortés me encargó un Réquiem, y desapareció. En ese momento me senté a escribir, y desde entonces no volvió por mí el hombre de negro; y estoy contento: sería una lástima separarme de mi trabajo, aunque está completamente listo el Réquiem. [...] Día y noche no me deja en paz el hombre de negro. Como sombra tras de mí por todas partes me persigue. Y ahora me parece está él sentado con nosotros. ${ }^{70}$

En I843, Oulibicheff publicó en Moscú una biografía de Mozart en francés, ${ }^{71}$ traducida al ruso por Modest Tchaikovsky (hermano menor del compositor). Oulibicheff escribe:

La cantidad de detractores de Mozart era aún mayor, debido a la tosca sinceridad de su carácter, y no se contenía ni en las cartas ni en la conversación. Abiertamente se expresaba de todos y sobre todo, como si no fuera suficiente su colosal talento para provocar el odio de aquellos a quienes criticaba. Entre los músicos italianos que vivían en Viena, había suficientes avezados para entender que Mozart trabajaba en su extinción, que su ópera alemana era el primer golpe al imperio de la música italiana, que los bárbaros Tedeschi [alemanes] finalmente les arrancarían de las manos el cetro del arte musical, al igual que sus antepasados bárbaros arrancaron de las manos de Italia el cetro del dominio en todo el mundo. Muchos músicos

70. “Человек, одетый в черном, Учтиво поклонившись, заказал/Мне Requiem и скрылся. Сел я тотчас /И стал писать - и с той поры за мною /Не приходил мой черный человек; /А я и рад: мне было 6 жаль расстаться /С моей работой, хоть совсем готов / Уж Requiem. [...] Мне день и ночь покоя не дает Мой черный человек. За мною всюду / Как тень он гонится. Вот и теперь Мне кажется, он с нами сам-третей Сидит." в Пушкин, Моцарт и Сальери, Сцена II, I7-24, 27-30 [Pushkin, Mozart y Salieri, escena II, 17-24, 27-30] (trad. del autor) (Véase anexo I).

7I. Alexandre Dimitrievich Oulibicheff, Nouvelle biographie de Mozart, suivie d'un aperçu sur l'histoire générale de la musique et de l'analyse des principaux ouvrages de Mozart (Moscú: Semen, I843). 
alemanes que tuvieron la torpeza de envidiar a Mozart se unieron a los italianos. De todos estos enemigos de Mozart, sólo uno pasó a la historia - Salieri. ${ }^{72}$

Pero al inicio del siglo XIX, no sólo se trataba de la irrupción de Mozart en el centenario predominio de la ópera italiana en Austria, sino también en San Petersburgo y Moscú. En el diario de Vincent y Maria Novello, que rememora su visita de I829 a Constanze Maria Weber en Salzburgo, se afirma: "La última vez que escuchó [Constanze] Don Giovanni estuvo intranquila durante las dos semanas siguientes. En Praga es donde le parece que se han ejecutado mejor las óperas, y también en Viena algunas veces, pero ahora, mientras están allí los cantantes italianos, no hay oportunidad de escuchar las óperas de Mozart; cuando se marchan, se representan." ${ }^{33}$

Ciertamente la confrontación con los italianos y su ópera tenía una larga tradición. En Francia se remontaba a la obra de François Raguenet: Parallèle des Italiens et des Français en ce qui regarde la musique et les opéras (I702), iniciando una larga disputa literaria. En 1752 continuó con la querelle des bouffons, en torno a la Serva padrona de Pergolesi puesta en escena por una compañía de buffoni en París, provocando una fructífera disputa en la estética sobre la relación del lenguaje y la música en la ópera.

En 1767 la querelle continuó con el prefacio a la ópera Alceste del compositor bohemio Christoph Willibald Gluck y libreto de Ranieri Calzabigi, estrenada en el Burgtheater de Viena. Gluck planteaba una reforma a la ópera, basada

72. „Количество недоброжелателей Моцарта было ещё больше оттого, что по несколько резкой откровенности своего характера, онъ не сдерживалься, ни въ письмахъ, ни въ разговоръ. Онъ прямо высказывался обо всехъ и обо всемъ, какь буто недостаточно было его колоссального таланта, чтобы возбудить ненависть техъ кого онъ критиковалъ. Между италианскими музыкантами, жившими въ Вене, было много достаточно просвещенныхъ чтобы понять что Моцарт работаль на ихъ погибель, что его немецкая опера была первымъ ударомъ царству италианской музыки, что варвары Tedeschi въ конце концовъ вырвуть изъ ихъ рукъ скипетръ музыкальнаго искусства, подобно тому какъ ихъ предки-варвары вырвали изъ рукъ Италии скипетръ обладания всемъ миромъ. Многие немецкие музыканты, имевшие глупость завидовать Моцарту, присоединились къ италианцамъ. Изъ всехъ этихъ враговъ Моцарта одинъ только перешелъ въ историю - это Салиери“, en А. Д. Улыбышев. Новая Биограбия Моцарта. Переводь М. Чайковскаго, съ примечаниями Г. Лароша. Томъ I-3. Издатель П. Юргенсона, Москва I890, 86-87 [A. D. Oulibicheff, Nueva biografía de Mozart, trad. M. Tchaikovsky (Moscú: Jurgenson, I890), 86-87] (trad. del autor).

73. Medici \& Hughes, A Mozart pilgrimage, IO2 (trad. de Gabriela Bustelo en Landon, I79I: El último año de Mozart, 22I). 
en el supuesto de una musicalidad originaria de la poesía que se revela en su propia declamación. La idea se remonta a las raíces del recitar cantando florentino, y tuvo su fundamentación filosófica en la obra de Rousseau sobre el origen común del lenguaje y la música. ${ }^{74}$

Esta idea, compartida por otros enciclopedistas, reforzaba la teoría romántica del carácter nacional de la música, y por otra parte, la antimusicalidad de algunas lenguas (nórdicas), así como la superioridad de la melodía sobre la armonía. Pero tras la escenificación de la versión francesa de Alceste (1776), y el drama heroico de Armide (1777), inició la disputa entre piccinistas, que defendían el bel canto italiano, como La Harpe y Marmontel, y los gluckistas que defendían su reforma..$^{75}$ Pushkin conocía bien la querelle y sobre la reforma de Gluck que Salieri había adoptado. En el primer monólogo de Salieri, Pushkin escribe:

¿Pero qué digo? Cuando el gran Gluck llegó y nos reveló nuevos secretos (profundos y encantadores secretos), ¿̇acaso no dejé todo lo aprendido, lo que amé, lo que ardientemente creí, y acaso no seguí vivamente su rastro, sumiso, como el que se pierde, y el que te encuentra te envía a otro lado? [...] nunca conocí la envidia, ¡Oh, nunca! —ni cuando Piccinni supo seducir el oído de salvajes parisinos, ni cuando escuché por vez primera los sonidos iniciales de 'Ifigenia'. ${ }^{76}$

74. Véase Jean Jaques Rousseau, Essai sur l'origine des langues où il est parlé de la mélodie et de l'imitation musicale. El ensayo fue redactado entre 1756 y 1762 , se publicó póstumamente en la Collection complète des œuvres de J. J. Rousseau (1782), por Pierre Alexandre Du Peyrou, ejecutor testamentario de Rousseau.

75. Véase Enrico Fubini, Los enciclopedistas y la música, M. Josep Cuenca, trad. Colección Estética \& Crítica (Universitat de València, 2002), 213-36. Antonio Salieri fue un protegido de Gluck y conocía bien sus ideas sobre la reforma en la ópera. Tras la querelle de I777, Gluck cedió a Salieri el libreto Le Danaidi de Calzabigi, traducido al francés por François-Louis Gand Le Bland Du Roullet y Louis-Théodore de Tschudi. Se estrenó el 26 de abril de 1784 en la Académie Royale de Musique de París. Se creía que Salieri la había compuesto bajo la dirección de Gluck. Fue en mayo de ese año que Gluck aclaró al Journal de Paris, que Salieri era el único autor de la obra.

76. “Что говорю? Когда великий Глюк Явился и открыл нам новы тайны (Глубокие, пленительные тайны), Не бросил ли я всё, что прежде знал, Что так любил, чему так жарко верил, И не пошел ли бодро вслед за ним, Безропотно, как тот, кто заблуждался И встречным послан в сторону иную? [...] никогда я зависти не знал, О, никогда! — ниже́, когда Пиччини Пленить умел слух диких парижан, Ниже́, когда услышал в первый раз Я «Ифигении» начальны звуки.” в Пушкин, Моцзарт и Сальери, Сцена I, 32-39, 49-54 [Pushkin, Mozart y Salieri, escena I, 32-39, 49-54] (trad. del autor) (véase anexo I). 
Salieri nunca visitó Rusia, pero su obra era bien conocida en San Petersburgo. ${ }^{77}$ En las memorias de Stepan Petrovich Dghixarev (I788-1860), ${ }^{78}$ que describen la vida teatral de Rusia entre I805 y I819, se menciona: "En el teatro alemán [...] se pueden escuchar óperas de Mozart, Salieri, Weigl, y otros célebres compositores."79 Dghixarev cita La Fiera di Venezia; Tarare; y Axur re d'Ormus de Salieri. ${ }^{80}$ No se sabe con certeza si Pushkin habría o no escuchado la obra de Salieri, pero es seguro que al menos sabía de Tarare, ya que la menciona en su pequeña tragedia: "Mozart: ¡Sí! En efecto Beaumarchais fue tu amigo; tú compusiste 'Tarare' para él, ópera maravillosa." ${ }^{81}$

77. Como en el resto de Europa, en el siglo xviII los italianos dominaron la escena teatral en Rusia. En 1736 llegó la primera compañía de ópera italiana dirigida por Francesco Araja, quien escenifica La forza dell'amore e dell'odio. Ese mismo año se crea la ópera italiana de la corte bajo la dirección de Araja, al ser nombrado maestro di cappella de su majestad Anna Ioanovna. En 1748 Araja es comisionado como director de los Concerti di musica italiana. En I762 Vincenzo Manfredini es contratado como maestro di capella y compositor de la corte de Ekaterina II. En I764 le siguió Baldassare Galuppi, que permaneció en Rusia hasta I768. Su sucesor fue Tommaso Traetta. En 1776 es invitado Giovanni Paisiello, y lo sustituye Giuseppe Sarti como director de la cappella imperial en 1783 . En 1787 llega a Rusia Domenico Cimarosa, quien abandona la corte en junio de I79I, invitado por Leopoldo II a Viena, donde compone en febrero de 1792 su obra maestra: Il matrimonio segreto. Ese mismo año Giuseppe Sarti ocupa de nuevo su puesto. Véase Olga Chkourak, "Inicio y consolidación de la teoría del pianismo ruso. Estudio Comparativo de dos Escuelas: Leonid V. Nikolaev (I878-I942), Heinrich G. Neuhaus (I888-1964)”, tesis doctoral (Madrid: Universidad Autónoma de Madrid-Departamento de Música, 2010), 23-26.

78. С. П. Жихарев. Записки современника. Изд. Академии Наук СССР, Ленинград, І955. [S. P. Dghixarev, Memorias de un contemporáneo (Leningrado: Academia de Ciencias URSS, 1955)]. La obra se publicó parcialmente por vez primera en la revista Москвитянин [El Moskovita] de I853. En I859 se publicó un primer volumen, con el título: Записки современника [Memorias de un contemporáneo]. Fue una importante fuente de información para la novela de Lev Tolstoi: La guerray la paz.

79. "На немецком театре можно слышать оперы Моцарта, Сальери, Вейгля и других знаменитых композиторов”, еп Жихарев, Записки современника, 40I-402 (trad. del autor).

80. La Fiera di Venezia: libreto de G. Boccherini; estrenada el 29 de enero de 1772 en el Burgtheater de Viena. Tarare: libreto de Pierre-Augustin Caron de Beaumarchais; estrenada en París el 8 de junio de 1787. Axur, re d'Ormus: versión italiana de Tarare con libreto de Lorenzo da Ponte; se estrenó en enero de 1788 en Viena. A solicitud de Beaumarchais, Tarare se reestrenó en París en 1790 para el primer aniversario de la toma de la Bastille, con el título: Le Couronnement de Tarare, que incluye el célebre canto revolucionario Ça ira. Véase Thomas Betzweiser y A. Groos, "Exoticism and Politics: Beaumarchais' and Salieri's 'Le Couronnement de Tarare' (1790)", Cambridge Opera Journal I6, núm. 2 (julio de 1994): 9I-II2.

8I. “Моцарт: Да! Бомарше ведь был тебе приятель; Ты для него «Тарара» сочинил, Вещь славную." в Пушкин, Моцарт и Сальери, Сцена II, 36-38 [Pushkin, Mozart y Salieri, escena II, 36-38 (trad. del autor) (Véase anexo I). 


\section{Mozart y Pushkin}

Una de las fuentes de inspiración más importantes de Pushkin fue la lectura de una carta apócrifa atribuida a Mozart, publicada en la revista Hijos de la Patria de St. Petersburgo en 1827, con el título: Моиартово письмо [Carta de Mozart]. La carta había sido publicada el 23 de agosto de I8I5 por Johann Rochlitz, en la Allgemeine Musikalische Zeitung de Leipzig, titulada: "Schreiben Mozarts an den Baron von..." ${ }_{2}$

La carta se hizo célebre en las siguientes décadas y fue objeto de frecuentes publicaciones y traducciones, asegurando su legitimidad. En la carta Mozart explica a un tal barón von... sobre su proceso creativo, siendo en esencia el mismo proceso que el poeta romántico experimentaría. De ahí tal vez la principal motivación de Pushkin para escribir esta obra; su identificación con Mozart. ${ }^{83}$ El pseudo-Mozart escribe:

Usted desea saber de qué manera yo compongo y escribo una simple pieza musical. Lo que puedo decir sobre esto es lo siguiente: yo mismo no sé nada más, y no puedo describirlo. Cuando estoy libre, totalmente solo y de buen humor, por ejemplo viajando en diligencia, o caminando después de una buena comida, o durante la noche, cuando no puedo dormir; mis ideas fluyen mejor y son más abundantes. De dónde y cómo llegan, no lo sé, pero yo no puedo forzarlas. Aquellas ideas que

82. Johann F. Rochlitz, ed., "Schreiben Mozarts an den Baron von...", Allgemeine Musikalische Zeitung (I8I5): 56I-566. Sobre la historia y análisis de esta carta, véase: Arturo García Gómez, "Carta a un tal barón von... de W. A. Mozart sobre el proceso creativo", Anales del Instituto de Investigaciones Estéticas XXXIX, núm. IIO (2017): 9-48.

83. En sus conversaciones con Nadezhda Mandelstam, la poetisa Anna Akhmatova sostiene la versión del poeta Osip Mandelstam, de que Pushkin se identificaba más bien con Salieri que con Mozart, lo cual resulta paradójico, ya que se tiene la idea de que la "inspiración" no exige ningún trabajo, y de que Pushkin escribía su poesía con la espontaneidad de un "pájaro divino" [птичка Божия], es decir, como Mozart componía su música, sin esfuerzo alguno. Osip Mandelstam afirma que Pushkin no se refería al poeta como al "pájaro divino", que sacude sus alas y canta porque tiene un acuerdo natural con Dios, "honor que no se atrevería a sońar ni el más genial poeta”. Véase Надежда Мандельштам. «Моцарт и Сальери» // Воспоминания. Книга третья. [(París:YMCA-PRESS, 1987), 22-23]. Птичка Божия [Pájaro divino] son unos versos del poema Gitanos (I824) de Pushkin, en el que se confrontan dos visiones del mundo: los gitanos libres y Aleko, que se esconde de la ley entre ellos. Aleko acepta la forma de vida de los gitanos, pero no su visión del mundo. Los versos dicen: El pájaro divino no sabe / no se preocupa, ni trabaja [...] El pájaro al ojo de dios atiende, / sacude sus alas y canta [trad. del autor], en A. C. Пушкин. Собрание Сочинений (Том третий, Москва, I975), І44-I45. 
me agradan las ordeno (klassificire [sic]) en mi memoria, y como me han dicho, tengo el hábito de tararearlas (trällern) en voz baja. Después, trato de hacer con uno u otro trozo algo formado, es decir, conforme a las reglas del contrapunto, y de sonoridad especial en diversos instrumentos, et caetera. Todo esto enciende mi alma, siempre y cuando no sea molestado, y mi obra crece por sí misma, se define y toma una forma determinada, e incluso, aunque ésta no sea muy sencilla, resulta casi lista en mi mente, de tal manera que la abarco en una sola mirada como a un hermoso cuadro o estatua; además, en mi imaginación no la escucho parte por parte, sino inmediatamente, como si fuera en su totalidad. El encanto que provoca esto no lo puedo describir. Toda esta invención y creación sucede como en un placentero y vívido sueño. Pero lo mejor de todo esto es que precisamente el oído abarca la totalidad en un solo momento. Lo que se ha producido no lo olvido fácilmente, y posiblemente esto sea el más valioso regalo, el cual debo agradecerle a mi creador. Cuando procedo a escribir mis ideas, saco de la bolsa de mi memoria, si se puede usar tal expresión, aquellas que han sido recolectadas en ella, de la manera que he mencionado. Por esta razón, ponerlo sobre el papel es bastante rápido, y todo está, como ya lo he dicho, totalmente terminado, y raramente difiere en el papel de lo que fue en mi imaginación. En esta ocupación, sin embargo, no puedo ser molestado; y pase lo que pase a mi alrededor sigo escribiendo, e incluso hablando, pero sólo de gallinas o huevos, o de Maria y Praskovia [*], y ese tipo de cosas. Pero por qué mi creación toma esa forma en mis manos, esa particular forma y estilo que llaman mozartiana, que la distingue de las obras de otros compositores, es probablemente debido a la misma causa que mi nariz tenga tal anchura y tal forma aguileńa, esto es, lo que la hace mozartiana y diferente a las de otras personas. Yo no me esfuerzo en ser original, y no sabría en realidad expresar en qué consiste mi originalidad, aunque me parece muy natural que la gente, que tiene su propia apariencia, por supuesto que están organizadas en diferente forma de los otros, tanto por dentro como por fuera. Pero al menos sé que yo no me creé a mí mismo, ni de una, ni de otra forma. ${ }^{84}$

84. “Вы желаете знать, какимь образомь я сочиняю и пишу пространныя музыкальныя пьесы. Въ нижеследующемъ заключается все, что я могу сказать о томъ; боле самъ я ничего не знаю и не въ состоянии обьяснить. Когда случается мне быть на свободе, совершенно одному и въ повозке, во время путешествия, или на прогулке после порядочнаго обеда, или ночью, когда не спится - тутъ всего лучше и всего изобильнее собираются и стремятся ко мне идеи. Откуда, и какъ приходять они, того я не знаю, но я производить ихь не могу. Те идеи, которыя мне нравятся, распределяю я по порядку (klassificire) въ моей памяти, и какъ мне сказывають, имею привычку, напевать (trällern) ихъ тихимъ голосомъ. Потомъ стараюсь 
Tras la lectura de esta carta, es sorprendente constatar cómo Pushkin expone de manera apofática en su tragedia el proceso creativo mozartiano. Es decir, Pushkin no describe a Mozart, sino al racional y tortuoso proceso de composición de Salieri, quien dice: "Con sonidos muertos disequé la música como a un cadáver. Y confié en el álgebra de la armonía." ${ }^{85}$ Éste es el punto central de la obra, ya que la frustración creativa de Salieri, basada en el esfuerzo

я ту или другую штуку наладить такъ, чтобъ сделать изъ нея что нибудь порадочное, то есть, по правиламъ контрапункта, особаго звука различныхъ инструментовъ и т. д. Все это меня одушевляетъ, и если не помешаютъ мне, то предметъ мой увеличивается, становятся правильнымъ, получаетъ определительную форму, и даже, хотя бы онъ былъ и оченъ пространенъ, почыи совсемъ оканчивается и усовершается у меня на уме, такъ, что я однимъ взглядомъ могу обозреть его, какъ прелестную картину или статую; а при томъ въ своемъ воображении слышу я части, не одну за другою, но какъ будто бсе вдругъ. Какое возхищение доставляетъ это, я не могу пересказать. Все изобретение и творение производится какъ будто въ приятномъ, явственномъ сновидении. Но самое лучшее при томъ именно то, что слухъ обьемлетъ все целое вдругъ. Уже я никакъ не забываю того, что совершилось такимъ образомъ, и можетъ быть, это самый драгоценный даръ, за который долженъ благодарить Творца своего. Когда сажусь писать свои идеи, то уже только вынимаю изъ своего, если смею такъ выразиться, памятнаго мешка все то, что собралъ тамъ, какъ было сказано. По сейто причине записывание идетъ у меня очень скоро, ибо, какъ я упомянулъ, я кладу на бумагу почти все готовое и редко отступаю при томъ отъ того, что заложено въ моемъ воображении. Посему-то при этой работе, я могу сносить всякую помеху; что бы вокруг меня ни происходило, я продолжаю писать, и даже говорю въ это время, но только о курахъ, да объ яицахъ, о Машиньке, да о Парашиньке [*], и о подобныхъ вещахъ. Но что мои творения получаютъ отъ моей руки особую форму и особенный стиль, которые называются Моцартовскими, и что они отличаются отъ произведений другихъ композитеровъ - этому вероятно та же причина, по которой носъ мой имеетъ такую толщину и такую орлино-кривую форму, что это Моцартовъ носъ, а вовсе не такой, какъ у другихъ людей. Я точно не делаю никакого напряжения и не стараюсь быть оригинальнымъ, да и не умелъ бы въ самомъ деле выразить, въ чемъ состоитъ моя оригинальность, хотя мне и кажется весьма естественнымъ, что люди, имеющие свою собственную наружность, конечно иначе организованы, нежели другие люди, какъ снаружи, такъ и внутри. Знаю по крайней мере то, что я не самъ себя создалъ, ни въ томъ, ни въ другомъ отношении”, еn Моцартово письмо // Сьнъ Отечества, журналь литературы, политики и современной истории, часть ІІ6, Санкт-петербургъ I827, 215-217 ["Carta de Mozart", Hijos de la Patria. Revista de Literatura, Politica e Historia Contemporánea, núm. II6 (San Petersburgo, I827), 215-I7] (trad. del autor). *En el original, Mozart se refiere a "Gretel und Bärbel”, diminutivos de Margarethe y Barbara. Véase García Gómez, Carta a un tal barón von..., 20.

85. “Звуки умертвив, Музыку я разъял, как труп. Поверил Я алгеброй гармонию”, в Пушкин, Моцарт и Сальери, Сцена I, I9-2I [Pushkin, Mozart y Salieri, escena I, I9-2I] (trad. del autor) (Véase anexo I). 
y la abnegada dedicación, que sacrifica diversiones para entregarse de lleno al interminable y sinuoso proceso de prueba y error, es el motor que lo impulsa a envenenar a Mozart. En esencia, se trata del fracaso que la razón asume ante la libertad creadora de la naturaleza, exigiendo justicia a la naturaleza misma.

En la homofonía lingüística anglogermana 'Gift-Gift' [don-veneno], Pushkin encuentra una sinonimia poética de oposición semántica 'яд-дар' [veneno-regalo], del veneno como un regalo. El único don que la naturaleza ofrece a Salieri es el veneno que le regala Isaura, guardado desde su primer encuentro con Mozart: "He aquí el veneno, último regalo de mi Isaura. Dieciocho ańos lo llevo conmigo y la vida me pareció desde entonces una insoportable herida [...] ¡Llegó la hora! Regalo íntimo de amor, pasa ahora al cáliz de la amistad." ${ }^{86}$

Isaura es una invención de Pushkin comparada al arquetipo de la Parca shakesperiana; de la arcaica Moira [Moĩpa] que promete a Macbeth el trono, incentivando su ambición. Al envidiar Salieri la genialidad de Mozart, se convierte en víctima del regalo de Isaura. En víctima de la arcaica reliquia de reciprocidad del veneno como regalo. Y con este obsequio, en nombre de la razón, Salieri es predestinado a vengarse del genio creador. ${ }^{87}$

\section{La evolución filosófica de Pushkin}

Las 'escenas dramáticas' fueron el punto de inflexión en la evolución del pensamiento estético y filosófico de Pushkin, que va de la razón ilustrada en la filosofía francesa, al romanticismo de la filosofía alemana. ${ }^{88} \mathrm{El}$ joven poeta pasó

86. “Вот яд, последний дар моей Изоры. Осьмнадцать лет ношу его с собою - И часто жизнь казалась мне с тех пор Несносной раной [...] Теперь - пора! Заветный дар любви, Переходи сегодня в чашу дружбы”, в Пушкин, Моцарт и Сальери, Сцена I, I3I-34, I5I-56 [Pushkin, Mozart y Salieri, escena I, I3I-34, I5I-56] (trad. del autor) (Véase anexo I).

87. En sociedades arcaicas, según Marcel Mauss, el regalo recibido tenía un carácter obligatorio de reciprocidad. En el objeto donado reside algo del donante, y por medio de éste el donante obtiene poder mágico sobre el receptor, ya que regalar significa dar algo de sí mismo. Véase Marcel Mauss, Essai sur le don. Forme et raison de l'échange dans les sociétés archä̈ques (París: Presses Universitaires de France, 1950) (trad. de Julia Bucci, Ensayo sobre el don. Forma y función del intercambio en las sociedades arcaicas [Buenos Aires: Katz Editores, 2009]).

88. El poeta Dmitri Vladimirovich Venevitinov (I805-I827), primo lejano de Pushkin, influyó en la evolución de su pensamiento hacia el romanticismo. Junto al príncipe Vladimir Odoyevski (I803-I869), Venevitinov organizó una sociedad secreta de filosofía llamada: “Общество любомудрия" [Sociedad de amor a la sabiduría]. Sus miembros estudiaron la filosofía idealista 
de los cánones del clasicismo de Racine y Molière, a las nuevas ideas estéticas de los románticos como Byron y Goethe. Al ser un estudioso de los clásicos, que piensa en términos metafísicos absolutos, estáticos y unívocos como la libertad, la igualdad o el amor, y cuyo fundamento es la filosofía ilustrada francesa, Pushkin da un giro hacia el romanticismo alemán.

Si la vida es la verdad, y si en la poesía existe la verdad, que es siempre contradictoria, entonces la poesía debe representar las contradicciones de la vida. La verdad no es abstracta. El clasicismo francés es estático y unilateral, en cambio el romanticismo es dialéctico; voluble y ambiguo. ${ }^{89}$ Por ello Pushkin toma como modelo las Dramatic Scenes de Barry Cornwall. En febrero de I826, Pushkin escribe al barón Anton Delwig: "No seamos ni supersticiosos, ni unilaterales como los franceses trágicos; sino veamos la tragedia con la mirada de Shakespeare."90

En su análisis de Mozart y Salieri, Juri Lotman muestra que la unilateralidad, la abstracción y el pensamiento dogmático conducen al crimen. Antes de

alemana en las obras de Schelling, Kant, Fichte, Oken y Schlegel, entre otros. Junto a su hermano menor Aleksei Venevitinov, publicaron diversos artículos sobre la filosofía clásica alemana en la revista Московский Вестник [Mensajero Moscovita] que editó Mikhail Petrovich Pogodin de I827 a I829. En torno a esta revista se formó un círculo de escritores conocido comо московские шеллингисты [moscovitas schellingianos]. En esta revista Pushkin publicó por vez primera varias obras. Véase Н. И. Мордовченко. Веневитинов и поэты-любомудры // История русской литературы в десяти томах. М.; Л.: Изд-во АН СССР, І94І-І956. Том шестой. Литература I820-1830- х годов. 1953, 448-459 [N. I. Mordovchenko. "Venevitinov y los poetas-ljubomudry", en Historia de la literatura rusa en Io tomos, t.6 (M. L. Editorial Academia de Ciencias de la URSS, I94I-1956); Literatura de los años I820-I830s (1953), 448-59]. Por otra parte, en el catálogo de la biblioteca personal de Pushkin, que registra I,522 obras de literatura, historia y filosofía, se encuentran varios ejemplares de filosofía clásica alemana, en particular: L. F. Schön, Philosophie transcendantale, ou Système d'Emmanuel Kant (París: Ledoux, I83i) (núm. de catálogo, 136I). Véase Б. Л. Модзалевский. Библиотека А. С. Пушкина (Библиографическое описание). СПб: Типография Императорской Академии Наук, І9го [B. L. Modzalevsky, Biblioteca de A. S. Pushkin (San Petersburgo: Tipografía de la Academia de Ciencias Imperial, 1910)].

89. Véase, А. Пустовит. Пушкин и западноевропейская философская традииия. Монография. Киев, 2015, I6-32 [A. Pustovit. Pushkin y la tradición filosófica europea occidental. Monografía (Kiev, 2015), 16-32].

9о. “Не будем ни суеверны, ни односторонни — как французские трагики; но взглянем на трагедию взглядом Шекспира” еn А. С. Пушкин. Письмо І84. А. А. Дельвигу. Начало февраля I826 г. Из Михайловское в Петербург // Собрание сочинений. Том девятый. Письма I8I5-1830 годов, Москва «Художественная литература» 1977, 212 [A. S. Pushkin, "Carta I84. a A. A. Delwig. Inicio de febrero de I826. De Mijáilovskoye a St. Petersburgo", en Obra reunida en diez tomos. t. 9, Cartas I8I5-I830 (Moscú: Literatura Artística, 1977), 212] (trad. del autor). 
envenenar a Mozart, Salieri separa a la persona del genio, y deduce que esta persona, un 'loco y parrandero ocioso' no merece tal genio, y sólo después de este pensamiento lo condena a muerte..$^{9 \mathrm{I}}$

Según Hegel, en la tragedia se enfrentan dos verdades, dos puntos de vista, dos personajes, cada uno con su verdad, contradiciéndose mutuamente. La tarea del dramaturgo entonces es buscar la verdad sin dogmatismo; no inclinarse por ningún personaje; no culpar ni justificar a nadie. El veredicto final es la síntesis en la unidad de contrarios (principum coincidentiae oppositorum). Pushkin logra la madurez filosófica gracias a esta síntesis entre clasicismo y romanticismo, como el Renacimiento había sido también una síntesis entre la antigüedad pagana y la cristiandad medieval..$^{22}$

A la fecha se sigue especulando sobre la enfermedad final de Mozart, y los mozartianos afirman que la teoría del envenenamiento es insostenible. ${ }^{93}$ Si bien esto no fue un hecho histórico, la mitificación de su muerte sí fue el resultado de factores histórico-sociales, siendo Salieri el chivo expiatorio de rumores de salón, y la nota criminal periodística. Pero Mozart y Salieri no fue sólo la dramatización de un rumor que recorría Europa. Pushkin lleva la leyenda mozartiana a la verdad y la belleza artística de la tragedia. El mito adquiere entonces forma artística y contenido filosófico.

\section{Sintesis de forma y contenido en Mozart y Salieri}

Para la filosofía clásica alemana el arte es una síntesis de forma y contenido. Es la representación del pensamiento filosófico en modelos artísticos, que de manera intuitiva se formulan fuera del estudio filosófico mismo. No se trata de citar a la filosofía en las obras, sino de llevarla a cabo en modelos artísticos. En la evolución del pensamiento filosófico de Pushkin, cuyo objetivo era la recreación dinámica del cuadro del mundo, Mozart y Salieri adquiere una forma poética que se identifica con la dialéctica hegeliana. ${ }^{94}$

91. Véase Юрий Лотман. Пушкин. Биография писателя. Статьи и заметки. СПб.: Искусство, (1995), 308-310 [Juri Lotman, Pushkin. Biografía del escritor. Artículos y notas (San Petersburgo: Iskusstvo, 1995), 308-310].

92. Véase Пустовит, Пушкин и западноевропейская философская традиция, 42-43 [Pustovit, Pushkin, 42-43].

93. Véase Landon, I79I: El último año de Mozart, 67.

94. Véase Пустовит, Пушкин, Іо-II [Pustovit, Pushkin, Iо-II]. 
Un aspecto fundamental en la cosmovisión de la Antigüedad era la idea del eterno retorno de las cosas que se mueven en círculos. Según Heráclito, el tiem-

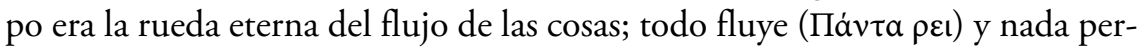
manece fijo en el devenir continuo de la "armonía de contrarios, como el arco y la lira" ${ }^{95}$ El círculo era la forma perfecta de movimiento. Pero en la era cristiana surge una nueva idea del tiempo, que se concibe como irrepetible. Si para el pensamiento antiguo el mundo era eterno, y su existencia se concebía como una interminable serie de ciclos, para la escatología cristiana el mundo fue creado ex nibilo y tenía un principio: la creación; y un fin: el juicio final. De esta forma la existencia del mundo se concebía ahora como un proceso lineal irreversible (apocatástasis).

La modernidad sintetizó estas dos etapas previas, y surge en la filosofía clásica alemana la teoría de un desarrollo en espiral que, de acuerdo a la dialéctica hegeliana, sería la ley de negación de la negación. Es la síntesis del movimiento circular y lineal, ya que en cada espiral hay un retorno al inicio, pero no literalmente, sino a otro nivel. Por supuesto que esta nueva concepción del tiempo y el desarrollo influyó en la creación artística, sobre todo en las artes temporales como la poesía y la música.

En realidad, muchas obras poéticas y musicales están escritas en forma simple de tres partes, cuyo esquema es: $\mathrm{ABA}$; o en forma rondó con dos episodios: ABACA. Ambas se caracterizan por su idéntico retorno al inicio, y son análogas del movimiento circular. Pero el pensamiento dialéctico condujo a una nueva forma musical con un retorno o repetición distinto, a otro nivel, como en la espiral: $\mathrm{A}^{\mathrm{I}} \mathrm{B} \mathrm{A}^{2}$.

La categoría principal de la dialéctica hegeliana es la contradicción. En la creación artística esta contradicción se revela en el conflicto dramático, que caracterizó a la música del siglo Xviı al xIx, y la forma que adopta es la llamada "sonata allegro". Boris Asaf'ev afirma que los compositores de la corte de Mannheim (ca. I740-I778), cuyo rasgo principal fue explotar los efectos dinámicos, son el punto de partida de formación del ciclo sonata-sinfónico. Su

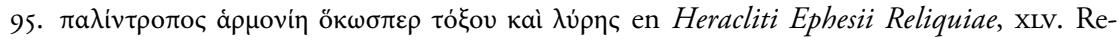
censuit I. Bywater (Oxonii, I877, I8) (trad. del autor). En su obra Le Mythe de l'éternel retour (195I), Mircea Eliade plantea que en la ontología arcaica hay un constante retorno al tiempo mítico de los orígenes, expresado en el mito del eterno retorno. La vida del hombre primitivo es la repetición ininterrumpida del otro, que remite cíclicamente a una ontología original de una realidad trascendente. Véase Mircea Eliade, El mito del eterno retorno. Arquetipos y repetición (Madrid: Alianza Editorial, 20I5). 
cristalización se logra en sinfonías de Haydn y Mozart. La rápida evolución de este tipo de formación musical en ascenso, coincide con el movimiento cultural que generó el romanticismo en Alemania.

Cuando leemos los ataques vehementes de Johann Georg Hamann contra el formalismo racional, y conocemos las majestuosas concepciones de Herder; cuando sufrimos los arrebatos tempestuosos e inquietos — fruto del exceso de fuerzas y sed de acción — de los héroes del drama de Klinger (Sturm und Drang, 1776) y de Friederich Müller; y finalmente, cuando caemos bajo el influjo de las frenéticas manifestaciones de Wilhelm Heinse y la desenfrenada fantasía de Bürger, entonces comprendemos que la música debió de seguir las huellas de su época, y que ésta realmente siguió creando la forma en la cual el principium concidentiae oppositorum y el conflicto - como fuerzas activas que se revelan a sí mismas en los modelos contrastantes- son los principales estímulos del movimiento. ${ }^{96}$

La forma sonata expresa la idea del desarrollo lineal y reversible de las cosas. Es una filosofía de la historia cristalizada en un nuevo ideal artístico, ya que sintetiza la idea cíclica de la Antigüedad con la idea del tiempo lineal e irreversible del cristianismo. Su diferencia con la forma simple de tres partes y el rondó es la misma que existe entre el movimiento en espiral y el movimiento en círculos. La forma sonata concreta el desarrollo como un movimiento del tiempo en espiral, que retorna al pasado pero a otro nivel, es decir, tras el desarrollo, la repetición o reprise no es literal sino distinta: $\mathrm{A}^{\mathrm{I}} \mathrm{B} \mathrm{A}^{2}$.

'Pushkinianos' y musicólogos coinciden en el análisis formal de Mozart y Salieri, al afirmar que sus cinco partes conforman su forma sonata: monólogo-diálogo-monólogo-diálogo-monólogo. Tiene dos personajes contrastantes

96. «Когда читаешь страстные выпады Иог. Георга Гамана против рассудочного формализма и знакомишься с величавыми концепциями Гердера; когда переживаешь бурные и беспокойные порывы — порождения избытка сил и жажды деятельности — героев драм Клингера («Sturm und Drang", I776) и Фридриха Мюллера; наконец, когда подпадаешь под влияние неистовых высказываний Вильгельма Гейнзе и необузданной фантазии Бюргера, - понимаешь, что музыка должна была идти вслед за современностью и что она действительно пошла за ней, создав форму, в которой principium concidentiae oppositorum и конфликт - как действующие силы, проявляющие себя в контрастных образах, - становятся руководящими стимулами движения.» в Борис В. Асафьев. Музыкальная форма как проиесс. Книги первая и вторая. Государственное Музыкальное Издательство. Ленинград, I963, I44-I45 [Boris Asaf' ev, La forma musical como proceso, lib. I y II (Leningrado: Editorial Estatal de Música, I963), I44-I45] (trad. del autor). 
que corresponden al tema principal y secundario de la exposición de la sonata. El núcleo de su forma lo constituyen sus diálogos, divididos por el segundo monólogo de Salieri, $\mathrm{A}^{\mathrm{I}} \mathrm{B} \mathrm{A}^{2}$ :

A (monólogo-diálogo); B ( $2^{\circ}$ monólogo); A $^{2}$ (diálogo-monólogo). Así, el primer monólogo corresponde a la introducción de la sonata. El primer diálogo es la exposición de temas contrastantes. El segundo monólogo es el desarrollo, y aunque es monólogo, Mozart está siempre presente en el pensamiento de Salieri. El segundo diálogo corresponde a la reexposición de los temas de manera distinta; y el tercer monólogo a la coda. ${ }^{97}$

\section{Sobre el genio creador y de la injusticia divina}

En su evolución hacia la filosofía clásica alemana, Pushkin reconocía en Mozart al genio creador que crea como el gusano de seda produce su seda, de manera intuitiva y sin esfuerzo consciente. Un genio al que el hambre de invención le era desconocida, y componer era sólo un problema de selectividad. Su seguridad en sí mismo, su fertilidad e ingeniosidad eran increíbles, resolviendo cualquier problema antes de que apareciera. En su tragedia, Pushkin advierte la medianía de Salieri ante la genialidad de Mozart. Y tanto su premisa de injusticia divina, como su decisión de venganza, son producto del cálculo consciente de Salieri por imponerse a la naturaleza. Ratio versus natura. Al final de su primer monólogo, Salieri clama justicia a la naturaleza: “¡Oh cielo! ¿Dónde estás justicia, cuando el don divino, cuando el genio eterno no es en premio del amor ardiente, del sacrificio, del trabajo, del esfuerzo y la plegaria, pero sí alumbras la mente del loco, del parrandero ocioso? ¡Oh Mozart, Mozart!"98

Mozart y Salieri representa el eterno conflicto de la creación artística

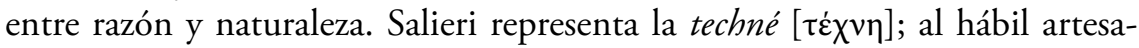

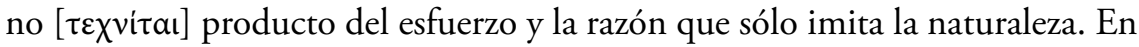

97. Véase А. В. Пустовит. Моцарт и Сальери // Этика и эстетика. Наследие Запада. История красоты и добра: Учеб. пособие. -К.: МАУП, 2006, с. 490 [A. V. Pustovit, "Mozart y Salieri”, Ética y estética. Herencia de occidente. Historia de la belleza y el bien (Kiev, 2006), 490] (Véase anexo II).

98. “О небо! Где ж правота, когда священный дар, /Когда бессмертный гений- не в награду Любви горящей, самоотверженья, Трудов, усердия, молений послан - А озаряет голову безумца, Гуляки праздного?.. О Моцарт, Моцарт!” в Пушкин, Моцарт и Сальери, Сцена I, 6o-66 [Pushkin, Mozart y Salieri, escena I, 6o-66] (trad. del autor) (Véase anexo I). 


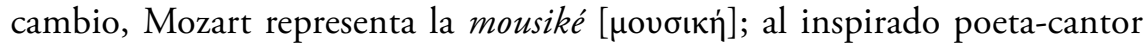
[ảoıঠóc] cuyo arte sólo proviene del don divino otorgado por las Musas. Salieri quiere ser genio y se esfuerza por serlo, imitando lo que hace la naturaleza. Pero Mozart no se esfuerza, porque él mismo es la naturaleza.

En el párrafo 46 de la Crítica del juicio, Immanuel Kant afirma que: "Las bellas artes son artes del genio. El genio es el talento (don natural) que da al arte su regla. Como el talento o el poder creador que posee el artista es innato, y pertenece por tanto a la naturaleza, se podría decir también que el genio es la cualidad innata del espíritu (ingenium), por la cual la naturaleza da la regla al arte." 99

Kant argumenta que el genio es aquel talento que produce sin reglas determinadas, y no la habilidad demostrativa, o aquello que se puede aprender según la regla. Por tanto la originalidad es su cualidad principal. Es un modelo a seguir que no se puede describir racionalmente, ya que es inspiración de la naturaleza: "y de este modo, el autor de una producción, siendo deudor a su genio, no sabe él mismo cómo se hallan en él las ideas" . ${ }^{\text {1oo }}$ Esto es exactamente lo que Mozart describe sobre su creación en la carta apócrifa publicada por Johann Rochlitz (su probable autor) ${ }^{\text {Ior }}$ en 1815 , traducida al ruso en 1827 . Su lectura bien pudo motivar y nutrir de ideas a Pushkin, y en ella el poeta mismo reconocería la naturaleza de su propio genio creador, a pesar de las objeciones de O. Mandelstam y A. Akhmatova (véase supran. 83 ).

El envenenamiento de Mozart simboliza en la tragedia de Pushkin la violencia que ejerce la razón contra la naturaleza, motivada por la soberbia ante su impotencia creadora. Salieri encarna a la ambición artística, que cree lograr, mediante el frío cálculo racional de formas preestablecidas y estricto apego a las reglas, su obra maestra. Su objetivo era convertirse en genio, y para alcanzar la genialidad necesitó de mucho esfuerzo y abnegación: "Pronto rechacé las diversiones; y las ciencias, ajenas a la música, me fueron odiosas; obstinado y altivo renuncié a ellas, y me entregué sólo a la música. Duro fue el primer paso, y árido el camino. Superé viejas adversidades. Coloqué mi oficio a los pies del arte; me hice artesano: y con dóciles dedos logré la agilidad seca y el oído seguro.”

99. Emanuel Kant, Crítica del juicio (Ciudad de México: Editores Mexicanos, 2000), I23. ıоo. Kant, Crítica del juicio, I24.

IOI. Véase Otto Erich Deutsch, "Spurious Mozart Letters", The Music Review, núm. XXIV (I964): I2I.

Iо2. “Отверг я рано праздные забавы; Науки, чуждые музыке, были Постылы мне; упрямо и надменно От них отрекся я и предался Одной музыке. Труден первый шаг, И скучен первый 
Pero su ambición y sacrificios no dieron fruto, ya que el verdadero genio no trabaja, sólo se divierte y crea. Por ello Salieri reclama a la naturaleza el no haberle premiado por sus esfuerzos, y ante la injusticia divina sólo le quedaba un camino, vengarse de la naturaleza haciendo justicia por su propia mano. Pero la justicia del don divino no se obtiene con violencia, ya que - "genio y maldad son incompatibles. ¿No es cierto?”, — dice Mozart a Salieri justo antes de ser envenenado. Al final, Salieri termina preguntándose: “¿Pero acaso tendrá razón, y no soy un genio? Genio y maldad son dos cosas incompatibles. No es cierto: - dice Salieri, - ¿Y Buonarroti? ¿o es un cuento de la obtusa y absurda multitud, y no fue un asesino el fundador del Vaticano?" ${ }^{\text {"o3 }}$

\section{Mozart y Salieri después de Pushkin}

El 7 de diciembre de I898, tras sesenta y seis años de la publicación de Mozart y Salieri, el compositor Nikolai A. Rimsky-Korsakov estrena en la escena de la compañía de ópera rusa de S. I. Mamontov de Moscú, su ópera Mozart y Salieri. Escenas dramáticas de A. S. Pushkin, opus 48 . El libreto es casi la obra íntegra de Pushkin, excepto por diecisiete versos del monólogo de Salieri. Rimsky-Korsakov introdujo citas de Don Giovanni y del Réquiem de Mozart, pero la ópera no tuvo mucho éxito.

Ochenta años después, inspirado en Mozart y Salieri de Pushkin, el dramaturgo inglés Peter Shaffer presentó el 2 de noviembre de 1979 en el National Theatre de Londres, su pieza dramática Amadeus. Posteriormente la obra se presentó en el Broadhurst Theatre de Broadway, y recibió en 198I

\footnotetext{
путь. Преодолел Я ранние невзгоды. Ремесло поставил я подножием искусству; Я сделался ремесленник: перстам Придал послушную, сухую беглость И верность уху”, в Пушкин, Моцарт и Сальери, Сцена I, 9-I9 [Pushkin, Mozart y Salieri, escena I, 9-I9] (trad. del autor) (véase anexo I).

I03. “Но ужель он прав, И я не гений? Гений и злодейство -Две вещи несовместные. Неправда: А Бонаротти? или это сказка Тупой, бессмысленной толпы - и не был Убийцею создатель Ватикана?” в Пушкин, Моцарт и Сальери, Сцена II, 70-75 [Pushkin, Mozarty Salieri, escena II, 70-75] (trad. del autor. Véase anexo I). El final sugiere la posibilidad de que Pushkin haya leído la carta de Carpani, publicada en Giornale di Letteratura, Scienze ed Arti, de 1824 (véase supra n. 42). En defensa de Salieri, Carpani se pregunta si "Michelangelo avrebbe avvelenato Raffaello? no: tanta iniquità non successe" [¿¿Miguel Ángel habrá envenenado a Rafael? no: tanta inequidad no sucede], en Carpani, Lettera del sig. G. Carpani, 268 (trad. del autor).
} 
el Tony Award for Best Play. En 1984 la obra fue adaptada al cine por Peter Shaffer y Miloš Forman, que recibió el Academy Award for Best Picture.

La obra de Shaffer es de hecho la dramatización de toda la historiografía aquí presentada; una ficción con evidentes cambios sustanciales condicionados por la estructura dramática de la pieza. La obra comienza en la "celda" de un manicomio, donde Salieri, tras intentar suicidarse, relata a un clérigo su historia. Al final, Salieri ocupa el lugar de Franz Xaver Süsmayr, quien anota en la partitura del Réquiem las indicaciones de Mozart en su lecho de muerte. Peter Shaffer y Miloš Forman presentan a un "genio idiota", a un bufón risueño y frívolo que con extrema ingenuidad se enfrenta a los serviles músicos cortesanos por el favor de Leopoldo II. Esta banal caracterización de Mozart se basa claramente en la obra de Wolfgang Hildesheimer (Mozart, 1977), que indignó a más de uno en su momento.

De hecho, tras asistir al estreno de Amadeus en París, varios colegas míos me manifestaron su irritación por la trivial caracterización de un payaso hollywoodense, acostumbrados a la solemne figura del genio creador de Mozart. Por ello, el objetivo de este artículo ha sido precisamente la desmitificación bufonesca del mito mozartiano, que desafortunadamente popularizó Amadeus en todo el mundo, para encauzar el mito en su vertiente estética, cuya esencia no es más que el inestable equilibrio dialéctico de la creación artística, entre la razón y la naturaleza. \& 
https://doi.org/10.22201/iie.18703062e.2020.117.2728

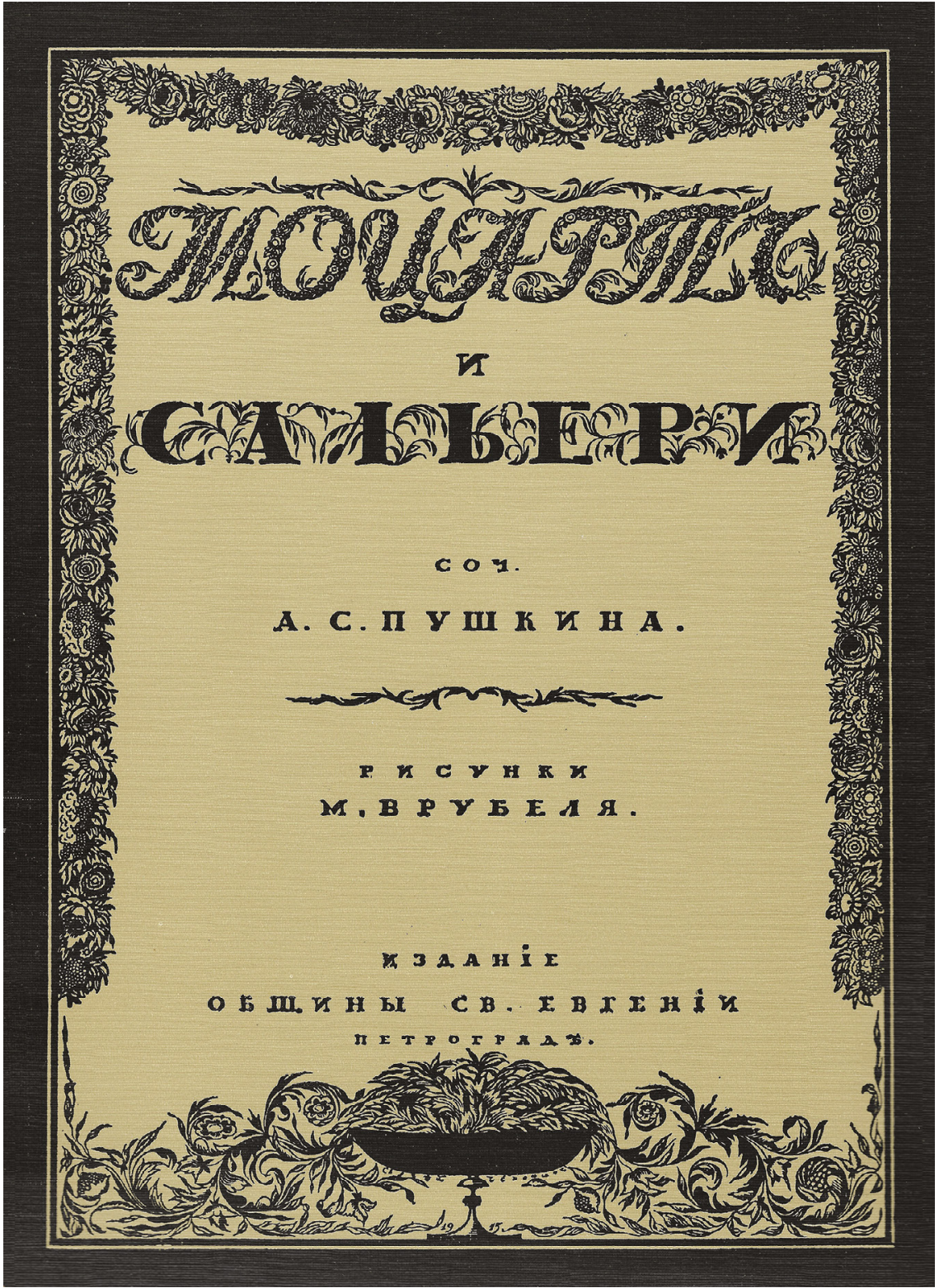

4. Portada de A. S. Pushkin, Mozart y Salieri, dibujos de M. Vrubel (San Petersburgo: Editorial Sociedad de San Eugenio, 1917 [ed. facsimilar, Leningado: Aurora Art Publishers, 1988]). 
Anexo

\author{
Anexo I. Traducción de Mozart y Salieri \\ Моцарт и Сальери ${ }^{104}$ \\ Сцена I \\ Комната \\ Сальери

\section{Mozart y Salieri \\ Escena I} \\ Alcoba [de Salieri] \\ Salieri
}

Bсе говорят: нет правды на земле.

Но правды нет - и выше. Для меня

Так это ясно, как простая гамма.

Родился я с любовью к искусству;

Ребенком будучи, когда высоко

Звучал орган в старинной церкви нашей,

Я слушал и заслушивался - слезы

Невольные и сладкие текли.

Отверг я рано праздные забавы;

10 Науки, чуждые музыке, были

Постылы мне; упрямо и надменно

От них отрекся я и предался

Одной музыке. Труден первый шаг,
Dicen que no hay verdad en este mundo.

Tampoco la hay en el cielo. Para mí

es claro como una simple escala.

Yo nací con amor al arte;

siendo niño, cuando sonaba alto

el órgano de nuestra vieja iglesia,

oía y escuchaba con lágrimas que

corrían involuntarias y dulces.

Pronto rechacé las diversiones; y

las ciencias, ajenas a la música, me

fueron odiosas; obstinado y altivo

renuncié a ellas, y me entregué sólo

a la música. Duro fue el primer paso,

I04. А. С. Пушкин. Моцарт и Сальери // Собрание сочинений в десяти томах. Том четвертый. Евгений Онегин. Драматические произведения. Москва “Художественная литература» 1975, с. 279-287 [A. S. Pushkin, "Mozart y Salieri”, en Obra reunida en diez tomos. t. 4. Evgeni Onegin. Obras dramáticas (Moscú: Literatura Artística, 1975), 279-287 (trad. de Arturo García Gómez y Olga Chkourak). Mozart y Salieri se tradujo por primera vez al francés en I862, por el escritor ruso Ivan Turgueniev y el francés Louis Viardot: Alexandre Pouchkine, Poëmes dramatiques d'Alexandre Pouchkine, traduit du russe par Ivan Tourguéneff et Louis Viardot (París: Librairie de L'Hachette et C, I862), I8I-I95. En 1985 se publicó la traducción al castellano del poeta mexicano José Emilio Pacheco, Don Juan o el convidado de piedra; Mozart y Salieri (Universidad Autónoma de Sinaloa, 1985). Como el mismo poeta afirma, Mozart y Salieri no fue traducido del ruso, sino del francés en la edición de Efim Grigorievitch Etkind, catedrático de la Facultad de Filología de la Universidad de Leningrado: Alexandre Pouchkine, Euvres complètes, t. II, Euvres poétiques, 2 vols. (Lausana: L’Age d'Homme, 198I). Esta triangulación dio como resultado imágenes alejadas del texto original, e incluso, la adición de líneas inexistentes en la obra de Pushkin. Por ejemplo, el traductor añade al final tres líneas que no pertenecen al texto: "Y yo no soy un genio como él y Mozart. No pasaré a la historia por mi música sino por ser el que ha matado a Mozart." Por todo ello, y con el objetivo de tener una fuente fidedigna para el análisis musicológico de esta obra, hemos realizado nuestra propia traducción al castellano cotejando línea por línea, quizá no tan inspirada poéticamente, pero sí al menos más apegada al texto original de Pushkin. 


\section{I36 ARTURO GARCíA GÓMEZ Y OLGA CHKOURAK}

И скучен первый путь. Преодолел Я ранние невзгоды. Ремесло Поставил я подножием искусству; Я сделался ремесленник: перстам Придал послушную, сухую беглость И верность уху. Звуки умертвив,

20 Музыку я разъял, как труп. Поверил Я алгеброй гармонию. Тогда Уже дерзнул, в науке искушенный, Предаться неге творческой мечты. Я стал творить; но в тишине, но в тайне, Не смея помышлять еще о славе. Нередко, просидев в безмолвной келье Два, три дня, позабыв и сон, и пищу, Вкусив восторг и слезы вдохновенья Я жег мой труд и холодно смотрел,

30 Как мысль моя и звуки, мной рождённый, Пылая, с легким дымом исчезали. Что говорю? Когда великий Глюк Явился и открыл нам новы тайны (Глубокие, пленительные тайны), Не бросил ли я всё, что прежде знал, Что так любил, чему так жарко верил, И не пошел ли бодро вслед за ним, Безропотно, как тот, кто заблуждался И встречным послан в сторону иную?

40 Усильным, напряженным постоянством Я наконец в искусстве безграничном Достигнул степени высокой. Слава Мне улыбнулась; я в сердцах людей Нашел созвучия своим созданьям. Я счастлив был: я наслаждался мирно Своим трудом, успехом, славой; также Трудами и успехами друзей, Товарищей моих в искусстве дивном. Нет! никогда я зависти не знал,

50 О, никогда! - ниже́, когда Пиччини Пленить умел слух диких парижан, Ниже́, когда услышал в первый раз Я «Ифигении» начальны звуки. Кто скажет, чтоб Сальери гордый был Когда-нибудь завистником презренным, Змеей, людьми растоптанною, вживе Песок и пыль грызущею бессильно? y árido el camino. Superé viejas adversidades. Coloqué mi oficio a los pies del arte; me hice artesano: y con dóciles dedos logré la agilidad seca y el oído seguro. Con sonidos muertos disequé la música como a un cadáver. Y confié en el álgebra de la armonía. Entonces me atreví a experimentar en ciencia, y me entregué al placer de sueńos creativos.

Comencé a crear; pero en silencio, en secreto, sin atreverme a pensar en la fama.

A menudo, sentado en mi quieta celda, olvidando dos, tres días comida y sueño, gocé el éxtasis y lágrimas de inspiración, al ver mi obra arder, con los sonidos

y pensamientos por mí creados, que en cenizas con ligero humo volaron. ¿Pero qué digo? Cuando el gran Gluck llegó y nos reveló nuevos secretos (profundos y encantadores secretos), ¿acaso no dejé todo lo aprendido, lo que amé, lo que ardientemente creí, y acaso no seguí vivamente su rastro, sumiso, como el que se pierde, y el que te encuentra te envía a otro lado? Con vehemencia e intensa constancia, finalmente logré en el arte infinito el más alto grado. La fama me sonrió; y en el corazón de la gente encontré consonancia de mi creación. Fui feliz: y disfruté apaciblemente mi trabajo, éxito, y fama; también las obras y éxitos de mis amigos, colegas míos del arte maravilloso. ¡No! nunca conocí la envidia, ¡Oh, nunca! —ni cuando Piccinni supo seducir el oído de salvajes parisinos, ni cuando escuché por vez primera los sonidos iniciales de "Ifigenia". Quien diga que Salieri fue altivo, o en algún momento un vil envidioso, ¿a la serpiente aplastan en vida, mordiendo arena y polvo impotente? 
Никто!.. А ныне- сам скажу - я ныне Завистник. Я завидую; глубоко,

60 Мучительно завидую. - О небо! Где ж правота, когда священный дар, Когда бессмертный гений- не в награду Любви горящей, самоотверженья, Трудов, усердия, молений послан А озаряет голову безумца, Гуляки праздного?.. О Моцарт, Моцарт!

\section{Входит Моцарт Моцарт}

Ага! увидел ты! А мне хотелось Тебя нежданной шуткой угостить. Сальери

Ты здесь! - Давно ль? Моцарт

Сейчас. Я шел к тебе,

70 Нес кое-что тебе я показать; Но, проходя перед трактиром, вдруг Услышал скрипку...Нет, мой друг, Сальери! Смешнее отроду ты ничего Не слыхивал...Слепой скрипач в трактире Разыгрывал voi che sapete. Чудо! Не вытерпел, привел я скрипача, Чтоб угостить тебя его искусством. Войди!

Входят слепой старик со скрипкой.

Из Моцарта нам что-нибудь.

Старик играет арию из «Дон Жуана»;

Моцарт хохочет.

Сальери

И ты смеяться можешь?

$$
\begin{aligned}
& \text { Моцарт } \\
& \text { Ах, Сальери! }
\end{aligned}
$$

80

Ужель и сам ты не смеешься?

$$
\text { Сальери }
$$

¡Nadie!...Y ahora — yo mismo les digo envidioso soy. Envidio sí; profundo y con pesar envidio. — ¡Oh cielo! ¿Dónde estás justicia, cuando el don divino, cuando el genio eterno no es en premio del amor ardiente, del sacrificio, del trabajo, del esfuerzo y la plegaria, pero sí alumbras la mente del loco, del parrandero ocioso? ¡Oh Mozart, Mozart!

\section{Entra Mozart \\ Mozart}

¡Ah, me viste! y quise hacerte

una bromita inesperada.

$$
\text { ¡Tú aquí! - ¿Hace mucho? }
$$

Ahora. Vine a visitarte,

Te traje algo que mostrar; resulta que al pasar por una taberna, de pronto escuché un violín... ¡No, mi amigo Salieri! Más divertido que esto jamás en la vida has escuchado... Un violinista ciego tocando en la taberna voi che sapete. ¡Maravilloso! No me contuve y traje al violinista, para compartir contigo su arte. ¡Entra!

Toca algo de Mozart para nosotros.

El anciano toca una aria del "Don Juan"

$$
\text { Mozart sonríe. }
$$
Salieri

¿Y puedes reírte?

Mozart

¡Qué pues, Salieri!

¿Será posible que no te rías?

Salieri

Нет.

Мне не смешно, когда маляр негодный Мне пачкает Мадонну Рафаэля, No me es gracioso cuando un mal pintor mancha a la Madona de Rafael. No, Мне не смешно, когда фигляр презренный no me es gracioso cuando un vil bufón Пародией бесчестит Алигьери. Пошел, старик. denigra con parodias a Alighieri. Largo de aquí anciano. 
Моцарт

Постой же; вот тебе,

Пей за мое здоровье. (Старик уходит.)

$$
\text { Ты, Сальери, }
$$

Не в духе нынче. Я приду к тебе В другое время.

$$
\text { Сальери }
$$

Что ты мне принес?

$$
\text { Моцарт }
$$

Нет - так; безделицу. Намедни ночью

90 Бессонница моя меня томила,

И в голову пришли мне две, три мысли.

Сегодня их я набросал. Хотелось

Твое мне слышать мненье; но теперь

Тебе не до меня.

$$
\text { Сальери }
$$

Ах, Моцарт, Моцарт!

Когда же мне не до тебя? Садись;

Я слушаю.

Моцарт (за фортепиано)

Представь себе...кого бы?

Ну, хоть меня - немного помоложе;

Влюбленного - не слишком, а слегка, -

С красоткой или с другом-хоть с тобой-

100 Я весел... Вдруг: виденье гробовое, Незапный мрак иль что-нибудь такое ... Ну, слушай же. (Играет.)

\section{Сальери}

Ты с этим шел ко мне

И мог остановиться у трактира

И слушать скрипача слепого! - Боже!

Ты, Моцарт, недостоин сам себя.

$$
\text { Моцарт }
$$

Что ж, хорошо?

$$
\text { Сальери }
$$

Какая глубина!

Какая смелость и какая стройность!

Ты, Моцарт, бог, и сам того не знаешь;

Я знаю, я.

$$
\text { Моцарт }
$$

Ба! право? Может быть ...
Mozart

Espera; aquí tienes,

Toma a mi salud [El anciano sale]

Tú, Salieri,

no estás de humor. Te visitaré

en otra ocasión.

\section{Salieri}

¿Qué me trajiste?

Mozart

No es nada; una bagatela. La otra noche el insomnio me torturaba, y se me ocurrieron dos tres ideas. Hoy las he bosquejado. Quisiera escuchar tu opinión; pero ahora no estás para mí.

\section{Salieri}

¡Ah, Mozart, Mozart!

¿Cuándo no he estado para ti? Siéntate;

Escucho.

$$
\begin{gathered}
\text { Mozart [al piano] } \\
\text { ¿Te imaginas... a alguien? }
\end{gathered}
$$

Bueno, aunque sea yo — algo más joven; enamorado — no demasiado, sino ligeramente, con una belleza, o un amigo — a lo mejor contigo -

estoy alegre... De pronto: una visión sepulcral, súbitas tinieblas o algo parecido...

Bueno, escucha [toca el piano]

\section{Salieri}

Con esto has venido a verme, y pudiste detenerte en la taberna a escuchar un violinista ciego! — Por Dios! Tú, Mozart, no eres digno de ti mismo.

Mozart

¿Qué, está bien?

\section{Salieri} ¡Cuanta profundidad!

¡Qué audacia y qué armonía!

Eres un Dios Mozart, y tú mismo no lo sabes; Yo sí lo sé, yo.

\section{Mozart}

¡Bah! ¡De verdad? Puede ser...

Pero mi divinidad tiene hambre. 


\section{Сальери}

Пожалуй: отобедаем мы вместе В трактире Золотого Льва.

\section{Моцарт \\ Пожалуй;}

Я рад. Но дай, схожу домой, сказать Жене, чтобы меня она к обеду

Не дожидалась. (Уходит.)

Сальери

Жду тебя; смотри ж.

Нет! не могу противиться я доле

Судьбе моей: я избран, чтоб его

Остановить, - не то мы все погибли,

Мы все, жрецы, служители музыки,

120 Не я один с моей глухою славой ...

Что пользы, если Моцарт будет жив

И новой высоты еще достигнет?

Подымет ли он тем искусство? Нет;

Оно падет опят, как он исчезнет:

Наследника нам не оставит он.

Что пользы в нем? Как некий херувим,

Он несколько занес нам песен райских,

Чтоб, возмутив бескрылое желанье

В нас чадах праха, после улететь!

130 Так улетай же! чем скорей, тем лучше.

Вот яд, последний дар моей Изоры.

Осьмнадцать лет ношу его с собою -

И часто жизнь казалась мне с тех пор

Несносной раной, и сидел я часто

С врагом беспечным за одной трапезой,

И никогда на шепот искушенья

Не преклонился я, хоть я не трус,

Хотя обиду чусвствую глубоко,

Хоть мало жизнь люблю. Всё медлил я.

140 Как жажда смерти мучила меня,

Что умирать? - я мнил: быть может, жизнь

Мне принесет незапные дары:

Быть может, посетит меня восторг,

И творческая ночь, и вдохновенье;

Быть может, новый Гайден сотворит

Великое - и наслажуся им ...

Как пировал я с гостем ненавистным,

Быть может, мнил я, злейшего врага

найду; быть может, злейшая обида
Salieri

Tienes razón: comamos juntos

en la taberna El León de Oro.

Mozart

Puede ser;

de acuerdo. Pero antes paso a casa, a decirle a mi mujer que no me espere a comer [Se marcha]

\section{Salieri}

Te espero; observa pues.

¡No! no puedo confrontar a

mi destino: fui elegido para

detenerlo, o todos sucumbimos,

somos sacerdotes al servicio de la música,

y no soy el único con sórdida fama...

¿Que beneficio hay si Mozart vive

y nuevas cumbres alcanza?

¿Elevará con eso el arte? No;

éste caerá en cuanto él desaparezca:

y no nos dejará un heredero.

¿Qué beneficio hay en él? Como querubín, nos ha traído del paraíso unas cuantas piezas, ¡para irritar los deseos sin alas de nuestros putrefactos restos, y después volar! ¡Pues vuela! mientras más pronto mejor. He aquí el veneno, último regalo de mi Isaura. Dieciocho años lo llevo conmigo y la vida me pareció desde entonces una insoportable herida, y estuve sentado con el enemigo indolente a la mesa, y nunca me entregué a la tentación del susurro, y aunque no soy miedoso, siento no obstante profundo la ofensa, aunque amo poco la vida. Mucho esperé Como una sed de muerte me torturaba, ¿acaso morir? yo pensé: puede ser que la vida me traiga regalos inesperados; puede ser que me llegue el éxtasis, la noche creativa y la inspiración; puede ser que un nuevo Haydn cree algo grandioso, y con ello me deleitaré... Anduve en festines con invitados odiosos, puede ser, yo creo, que encuentre al mortal enemigo; puede ser que la letal ofensa 
150 В мена с надменной грянет высоты Тогда не пропадешь ты, дар Изоры. И я был прав! и наконец нашел Я моего врага, и новый Гайдн Меня восторгом дивно упоил! Теперь - пора! Заветный дар любви, Переходи сегодня в чашу дружбы.

\section{Сцена II}

Особая комната в трактире; фортепиано. Моцарт и Сальери за столом. Сальери

Что ты сегодня пасмурен?

$$
\begin{aligned}
& \text { Моцарт } \\
& \text { Я? Нет! } \\
& \text { Сальери }
\end{aligned}
$$

Ты, верно, Моцарт, чем-нибудь расстроен? Обед хороший, славное вино,

А ты молчишь и хмуришься.

$$
\text { Моцарт }
$$

Признаться, мой Requiem меня тревожит. Sinceramente, mi Réquiem me preocupa.

$$
\text { Сальери }
$$

A! Ты сочиняешь Requiem? Давно ли?

$$
\text { Моцарт }
$$

Давно, недели три. Но странный случай ... Не сказывал тебе я?

$$
\begin{gathered}
\text { Сальери } \\
\text { Нет. } \\
\text { Моцарт } \\
\text { Так слушай. }
\end{gathered}
$$

Недели три тому, пришел я поздно

Домой. Сказали мне, что заходил За мною кто-то. Отчего - не знаю, Всю ночь я думал; кто бы это был? И что ему во мне? Назавтра тот же Зашел и не застал опять меня. На третий день играл я на полу С моим мальчишкой. Кликнули меня; Я вышел. Человек, одетый в черном, Учтиво поклонившись, заказал Мне Requiem и скрылся. Сел я тотчас

20 И стал писать - и с той поры за мною Не приходил мой черный человек; con altiva arrogancia estalle en mí, y entonces no te perderás, regalo de Isaura. ¡Y estuve en lo cierto! finalmente encontré a mi enemigo, y el nuevo Haydn con admirable entusiasmo me ¡sació! ¡Llegó la hora! Regalo íntimo de amor, pasa ahora al cáliz de la amistad.

\section{Escena II}

Gabinete reservado en la taberna; un piano. Mozart y Salieri a la mesa. Salieri

¿Porqué hoy tan triste?

$$
\begin{aligned}
& \text { Mozart } \\
& \text { ¿Yo? ¡No! } \\
& \text { Salieri }
\end{aligned}
$$

Seguramente, Mozart, a ti algo te perturba. Buena comida, vino maravilloso, y tú callado y hosco.

\section{Mozart}

Salieri

¡Ah! ¿Compones un Réquiem? ¿Hace mucho? Mozart

Hace tres semanas. Pero es un caso extraño... ¿No te he contado?
Salieri
No.
Mozart
Entonces escucha.
Hace tres semanas llegué tarde a casa.
Me dijeron que pasó por mí alguien.
Por qué — no lo sé, y toda la noche estuve pensando: ¿quien sería esta persona? ¿Y qué querría de mí? Al día siguiente el mismo tipo pasó, y de nuevo no estaba en casa. Al tercer día jugaba yo en el piso con mi hijo. Me llamaron y salí. Un hombre vestido de negro con reverencia cortés me encargó un Réquiem, y desapareció. En ese momento me senté a escribir, y desde entonces no volvió por mí el hombre de negro; y estoy 
А я и рад: мне было 6 жаль расстаться С моей работой, хоть совсем готов Уж Requiem. Но между тем я ...

$$
\begin{gathered}
\text { Сальери } \\
\text { Что? } \\
\text { Моцарт }
\end{gathered}
$$

Мне совестно признаться в этом ...

$$
\text { Сальери }
$$

В чем же?

\section{Моцарт}

Мне день и ночь покоя не дает Мой черный человек. За мною всюду Как тень он гонится. Вот и теперь

Мне кажется, он с нами сам-третей Сидит.

$$
\text { Сальери }
$$

И, полно! что за страх ребячий?

Рассей пустую думу. Бомарше

Говаривал мне: «Слушай, брат Сальери,

Как мысли черные к тебе придут,

Откупори шампанского бутылку

Иль перечти „Женитьбу Фигаро“».

$$
\text { Моцарт }
$$

Да! Бомарше ведь был тебе приятель;

Ты для него «Тарара» сочинил,

Вещь славную. Там есть один мотив ...

Я все твержу его, когда я счастлив ...

40 Ла ла ла ла ... Ах, правда ли, Сальери,

Что Бомарше кого-то отравил?

\section{Сальери}

Не думаю: он слишком был смешон Для ремесла такого.

Моцарт

Он же гений,

Как ты да я. А гений и злодейство -

Две вещи несовместные. Не правда ль?

Сальери

Ты думаешь? (Бросаем яд в стакан Моцарта.) Ну, пей же.

\section{Моцарт}

За твое Здоровье, друг, за искренний союз, Связующий Моцарта и Сальери, Двух сыновей гармонии. (Пьет.)

$$
\text { Сальери }
$$

contento: sería una lástima separarme de mi trabajo, aunque está completamente listo el Réquiem. Pero mientras tanto yo...

Salieri

¿Qué?

Mozart

Me avergüenzo reconocer que...

Salieri

¿De qué?

Mozart

Día y noche no me deja en paz el hombre de negro. Como sombra tras de mí por todas partes me persigue. $\mathrm{Y}$ ahora me parece está él sentado con nosotros.

Salieri ¡Ya basta! ¿qué es este miedo de niños? Dispersa el pensamiento vacío. Beaumarchais me decía: "Escucha hermano Salieri, si el pensamiento negro te visita, descorcha una botella de Champaigne, o relee las Bodas de Figaro".

\section{Mozart}

¡Sí! En efecto Beaumarchais fue tu amigo; tú compusiste Tarare para él, ópera maravillosa. Ahí hay un motivo que siempre lo repito cuando estoy feliz... La la la la... Ah, ¡es cierto Salieri, que Beaumarchais envenenó a alguien?

$$
\text { Salieri }
$$

No lo creo: él era muy simpático para tal oficio.

Él era un genio,

Mozart

como nosotros dos. Y genio y maldad son incompatibles. ¿No es cierto?

Salieri

¿Tú crees? [Arroja el veneno en el vaso de Mozart] ¡bien!, brindemos.

Mozart

A tu salud, amigo, por la sincera unión que enlaza a Mozart y Salieri, dos hijos de la armonía. [Toma]

\section{Salieri}

50 Постой, постой! ... Ты выпил! ... без меня? ¡Espera, espera!... ¡tomaste sin mí? 
Моцарт (бросает салфетку на стол) Довольно, сыт я. (Идет к фортепиано.) Слушай же, Сальери, Мой Requiem. (Играет.) Ты плачешь?

\section{Сальери}

Эти слезы

Впервые лью: и больно, и приятно, Как будто тяжкий совершил я долг, Как будто нож целебный мне отсек Страдавший член! Друг Моцарт, эти слезы... Не замечай их. Продолжай, спеши Еще наполнить звуками мне душу... Моцарт Когда бы все так чувствовали силу

60 Гармонии! Но нет: тогда 6 не мог И мир существовать; никто б не стал Заботиться о нуждах низкой жизни; Все предались бы вольному искусству. Нас мало избранных, счастливцев праздных, Пренебрегающих презренной пользой, Единого прекрасного жрецов. Не правда ль? Но я нынче нездоров, Мне что-то тяжело; пойду, засну. Прощай же!

Сальери

До свиданья (Один.)

Ты заснешь

70 Надолго, Моцарт! Но ужель он прав, И я не гений? Гений и злодейство Две вещи несовместные. Неправда: А Бонаротти? или это сказка Тупой, бессмысленной толпы - и не был Убийцею создатель Ватикана?
Mozart [arroja la servilleta a la mesa] Suficiente, estoy satisfecho. [Va al piano] Escucha mi Réquiem Salieri. [Mozart toca] ¿Estás llorando?

Estas lágrimas por primera vez derramo: amargas y dulces, como si cumpliera una penosa deuda, como si un escalpelo me quitara un miembro ¡enfermo! Amigo Mozart, no hagas caso a estas lágrimas. Continúa, apresúrate a llenar de sonidos mi alma... Mozart Cuando sintamos todos así ¡la fuerza de la armonía! Pero: entonces el mundo no existiría; nadie se ocuparía de las necesidades básicas de la vida; todos libres al arte se entregarían. Somos pocos elegidos, dichosos y festivos, que desdeñamos el vil provecho, única maravilla del sacerdocio. ¿No es cierto? Pero ahora estoy enfermo, y me siento mal; me voy a dormir. ¡Adiós!

\section{Hasta pronto [Solo.] ¡Te dormirás por} siempre, Mozart! ¿Pero acaso tendrá razón, y no soy un genio? Genio y maldad, son dos cosas incompatibles. No es cierto: ¿Y Buonarroti? ¿o es un cuento de la obtusa y absurda multitud, y no fue un asesino el fundador del Vaticano? 
Anexo II. Esquema de la forma sonata en Mozart y Salieri

\begin{tabular}{|c|c|c|c|c|c|}
\hline \multirow{2}{*}{$\mathrm{A}^{\mathrm{I}}$} & \multirow{2}{*}{\multicolumn{2}{|c|}{$\begin{array}{c}\text { Introducción } \\
\text { Exposición }\end{array}$}} & Introducción & \multirow{3}{*}{ Escena I } & \multirow{2}{*}{$\begin{array}{c}\text { Monólogo I } \\
\text { Diálogo I }\end{array}$} \\
\hline & & & & & \\
\hline B & \multicolumn{2}{|c|}{ Desarrollo } & & & Monólogo II \\
\hline \multirow{2}{*}{$\mathrm{A}^{2}$} & \multicolumn{2}{|c|}{ Reprise } & & \multirow{2}{*}{ Escena II } & Diálogo II \\
\hline & \multicolumn{2}{|c|}{ Coda } & & & Monólogo III \\
\hline \multicolumn{3}{|c|}{$\mathrm{A}^{\mathrm{I}}$} & B & \multicolumn{2}{|c|}{$\mathrm{A}^{2}$} \\
\hline Introducción & Exposi & ción & Desarrollo & Reprise & Coda \\
\hline \multicolumn{4}{|c|}{ Escena I } & \multicolumn{2}{|c|}{ Escena II } \\
\hline \multicolumn{4}{|c|}{ Exposición } & \multicolumn{2}{|c|}{ Reexposición } \\
\hline \multicolumn{4}{|c|}{ Diálogo I } & \multicolumn{2}{|c|}{ Diálogo II } \\
\hline \multicolumn{4}{|c|}{ En la alcoba de Salieri } & \multicolumn{2}{|c|}{ En la taberna El León de Oro } \\
\hline \multicolumn{4}{|c|}{$\begin{array}{l}\text { Jovial y alegre, Mozart entra en escena, en } \\
\text { contraste con la amargura de Salieri }\end{array}$} & \multicolumn{2}{|c|}{$\begin{array}{c}\text { Contrario a la primera escena, Mozart está } \\
\text { triste en tono con Salieri. }\end{array}$} \\
\hline \multicolumn{4}{|c|}{ Mozart ofrece una broma a Salieri } & \multicolumn{2}{|c|}{ Salieri ofrece una cena a Mozart } \\
\hline \multicolumn{4}{|c|}{ Salieri: ¡Tú aquí! - ¿Hace mucho? } & \multicolumn{2}{|c|}{$\begin{array}{c}\text { Salieri: ¡Ah! ¿Compones un Réquiem? } \\
\text { ¿Hace mucho? }\end{array}$} \\
\hline \multicolumn{4}{|c|}{ Mozart: Tú, Salieri, no estás de humor... } & \multicolumn{2}{|c|}{$\begin{array}{c}\text { Salieri: Seguramente, Mozart, a ti algo } \\
\text { te perturba... }\end{array}$} \\
\hline \multicolumn{4}{|c|}{$\begin{array}{c}\text { El anciano toca una aria del "Don Juan" de } \\
\text { Mozart }\end{array}$} & \multicolumn{2}{|c|}{ Mozart canta un motivo del Tarare de Salieri } \\
\hline \multicolumn{4}{|c|}{ Salieri corre al violinista } & \multicolumn{2}{|c|}{ Salieri despide a Mozart } \\
\hline \multicolumn{4}{|c|}{ Mozart: Espera; aquí tienes, Toma a mi salud. } & \multicolumn{2}{|c|}{ Salieri: ¡Espera, espera!... ¡¡tomaste sin mí? } \\
\hline \multicolumn{4}{|c|}{ Mozart toca el piano; Salieri en éxtasis } & $\begin{array}{r}\text { Moza } \\
\text { Sali }\end{array}$ & $\begin{array}{l}\text { Réquiem; } \\
\text { n éxtasis }\end{array}$ \\
\hline & Mozart sa & & & & queda \\
\hline Monólog & & & hólogo II & & ro III \\
\hline & alcoba d & le Salie & & En la tak & León de Oro \\
\hline $\begin{array}{r}\text { Salieri expo } \\
\text { formación, su } \\
\text { estéticas, y su en } \\
\text { Mozart }\end{array}$ & $\begin{array}{l}\text { su } \\
\text { ideas } \\
\text { dia por }\end{array}$ & $\begin{array}{r}\text { Sali } \\
\text { desti } \\
\text { enven }\end{array}$ & $\begin{array}{l}\text { i asume su } \\
\text { o, y decide } \\
\text { ar a Mozart. }\end{array}$ & $\begin{array}{r}\text { Salieri culmin } \\
\text { su p }\end{array}$ & $\begin{array}{l}\text { con la duda sobre } \\
\text { nialidad. }\end{array}$ \\
\hline
\end{tabular}

